Published in "Palaeogeography, Palaeoclimatology, Palaeoecology

376: 73-90, 2013"

which should be cited to refer to this work.

\title{
The lost paleosols: Masked evidence for emergence and soil formation on the Kimmeridgian Jura platform (NW Switzerland)
}

\author{
Richard Waite $^{\mathrm{a}, *}$, Daniel Marty $^{\mathrm{b}}$, André Strasser $^{\mathrm{a}}$, Andreas Wetzel ${ }^{\mathrm{c}}$ \\ a Départment de Géosciences, Université de Fribourg, Ch. du Musée 6, CH-1700 Fribourg, Switzerland \\ b Paléontologie A16, Section d'archéologie et paléontologie, Office de la culture, Hôtel des Halles, P.O. Box 64, 2900 Porrentruy 2, Switzerland \\ c Geologisches Institut, Universität Basel, Bernoullistrasse 32, CH-4056 Basel, Switzerland
}

\begin{abstract}
Lagoonal carbonates of Kimmeridgian age in NW Switzerland formed in a tropical epeiric sea and exhibit indicators of subaerial emergence such as tidal biolaminites, desiccation cracks, flat pebble conglomerates, and fenestral structures. Additionally, 30 dinosaur tracksites from at least six stratigraphic intervals indicate repeated formation of land bridges between the platform and adjacent massifs. Populations of herbivorous and carnivorous dinosaurs necessitate substantial vegetation and consequently a soil cover, but no striking evidence of paleosols have been found within the track bearing sequences. However, two stratigraphic levels exposed in nine outcrops exhibit distinctive hardgrounds that experienced early meteoric diagenesis during times of emergence. Initial induration began with the precipitation of thin micritic meniscus cements. Contemporaneously meteoric waters completely dissolved all aragonite leaving large voids. Iron-hydroxides were precipitated in the uppermost 7-10 $\mathrm{cm}$ where they impregnated the porous micrite and constituted a separate cement generation, which caused a penetrative dark red staining. These aspects are suggestive of the formation of Mediterranean-type red soils on the emerged platform. During transgression, the soil was eroded and wavecut hardgrounds were superimposed on the hardgrounds formed during regression. Erosion is evidenced by micro-karst, truncated Gastrochaenolites isp. borings and the physical removal of steinkerns. The eroded material including floral remains provided surplus nutrients leading to eutrophication. This food-rich environment supported the mass-occurrence of gastropods in the nerineoid limestones and oysters (Nanogyra sp.) in the Virgula Marls.
\end{abstract}

\section{Introduction}

During the Late Jurassic the area of the Swiss Jura Mountains was part of a vast epicontinental carbonate platform system within a shallow epeiric sea on the northern margin of the Tethys Ocean (Fig. 1). The study area at that time was located in the central part of the platform at a latitude of $\sim 32^{\circ} \mathrm{N}$ (Stampfli et al., 2001). The marine fauna and flora indicate tropical to subtropical water temperatures within a generally warm and globally rather equable climate (e.g., Frakes et al., 1992).

The absence of major evaporite deposits and the occurrence of woody plant remains in the latest Jurassic of Switzerland, England, France and Spain imply a semi-arid Mediterranean climate with strong seasonal differences between prolonged, warm, dry summers and relatively short, wet winters during the latest Jurassic in central Europe (Hallam, 1985; Abbink et al., 2001; Rees et al., 2004). Orbitallycontrolled high-frequency and low-amplitude sea-level changes, a few

\footnotetext{
* Corresponding author at: Paleontological Research Institution, 1259 Trumansburg Road, Ithaca, NY, 14850-1398, USA. Tel.: +1 60727366 23x27; fax: +1 6072736620. E-mail address: wairic00@gmail.com (R. Waite).
}

metres in range, were superimposed on the general second-order transgressive trend of the Late Jurassic (e.g., Hardenbol et al., 1998; Hallam, 2001; Colombié, 2002; Colombié and Rameil, 2007).

Resultant small base-level falls led to periodic emergence of the low-relief platform affecting wide areas and establishing land bridges (Marty et al., 2003; Meyer et al., 2006), as evidenced by numerous dinosaur-track-bearing levels in rocks dating from the Oxfordian to Berriasian Stages (e.g., Meyer and Thüring, 2003; Charollais et al., 2008; Mazin and Hantzpergue, 2010). The tracks are typically preserved in tidal-flat to supratidal-flat biolaminites (Meyer, 1990; Marty, 2008).

Paleosols, rhizoliths and shallow karst-indicating subaerial vadose environments - are common in the Lower Cretaceous deposits of the Swiss Jura Mountains (Hillgärtner and Strasser, 2003). In Kimmeridgian rocks, however, such indicators are rare; only one paleosol has been described from the lower Kimmeridgian (Gygi, 2003). Contrarily, dinosaur tracks are most abundant in the upper Kimmeridgian with over 30 tracksites from at least six different stratigraphic intervals (Meyer and Thüring, 2003; Marty et al., 2007). The dinosaurs depended on local food sources that imply a substantial vegetation cover. Fossil flora has been recovered from marl beds overlying the dinosaur track-bearing strata in two conspicuous intervals 


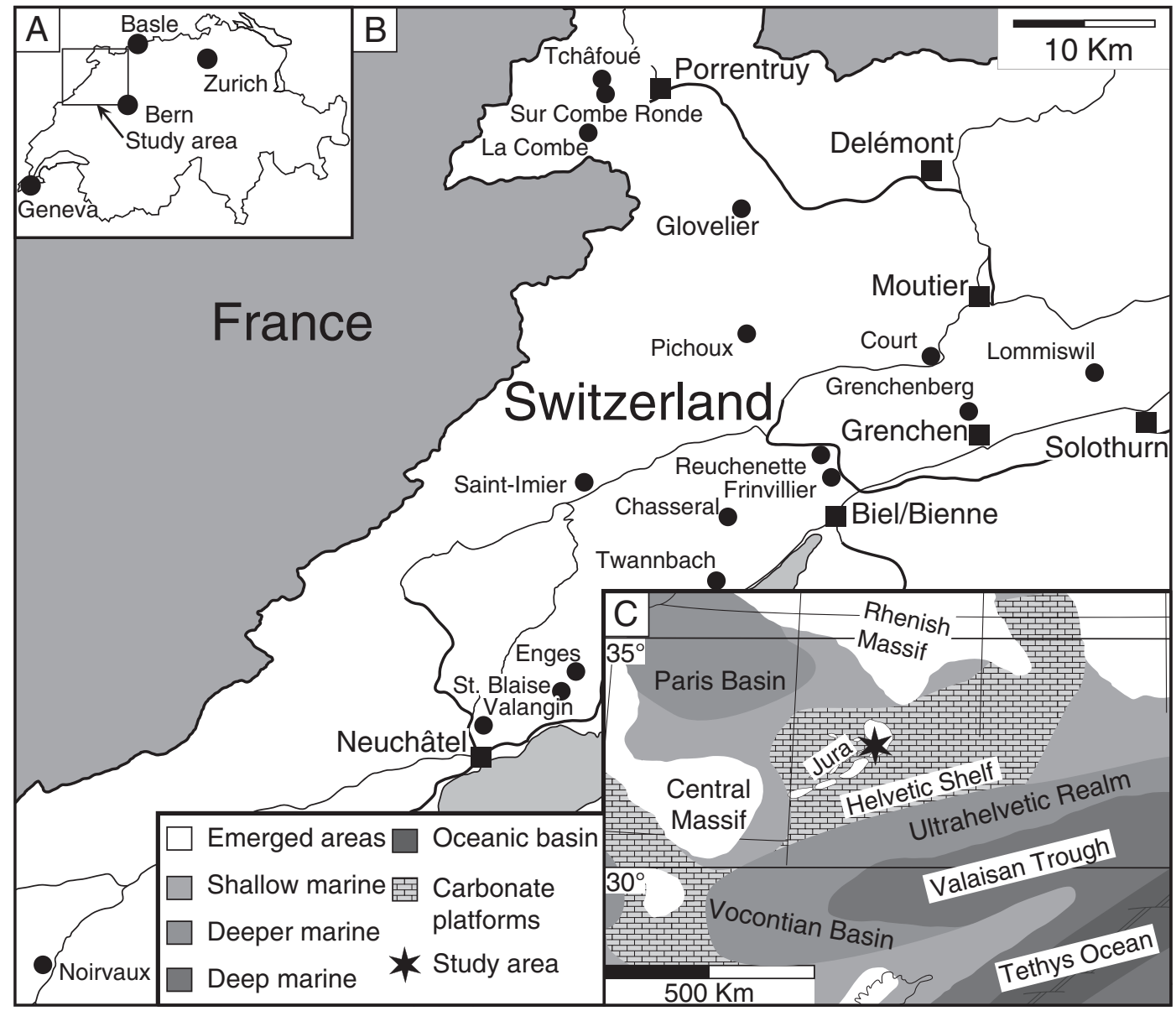

Fig. 1. Geographical and palaeogeographical overview of the study area. A) Location of study area within Switzerland. B) Roadmap of the study area in NW Switzerland showing outcrop locations. C) Palaeogeographical reconstruction of central Europe for the Late Kimmeridgian to Early Tithonian showing the position of the study area in its paleogeographical context. Modified after Thierry et al. (2000).

(Meyer, 1994; Philippe et al., 2010). Both dinosaur tracks and fossil flora point to the existence of soils but no direct evidence of a soil cover has been found so far. Thus, evidence for past soils must be unravelled from the incomplete stratigraphic record. Circumstantial evidence suggests that soils formed on indurated surfaces during sea-level lowstands but were subsequently eroded. Such surfaces are of stratigraphic and sequence-stratigraphic importance as they indirectly record depositional gaps in the rock record. It is the purpose of this paper to demonstrate that submarine hardgrounds below flooding surfaces can store information of previous emergence and that lost paleosols can thus be detected.

\section{Geological setting}

The study area is located in NW Switzerland (Fig. 1). All studied outcrops belong to the Reuchenette Formation, an $~ 90-160$ m thick succession of mainly light-coloured limestone $\left(\mathrm{CaCO}_{3}\right.$ content $\left.>95 \%\right)$ with occasional marl intercalations (Thalmann, 1966; Colombié, 2002). The Reuchenette Formation approximately corresponds to the Upper Jurassic Kimmeridgian Stage (Jank et al., 2006a,b; Fig. 2).

In the southern part of the study area, the upper limit of the Reuchenette Formation is formed by a conspicuous mass accumulation of nerineoid gastropods (Grenznerineenbank; Thalmann, 1966). These nerineoid limestones are commonly overlain by an interval of intercalated marls and limestones known as the upper Virgula Marls (=Praevirgula Marls of Thalmann, 1966; see Jank et al., 2006a). The marls and marly limestones contain abundant small, possibly mudreclining oysters of the genus Nanogyra Beurlen, 1958 (formerly described as Exogyra virgula Defrance, 1821) from where the Virgula Marls derive their name. Similar oyster-bearing marls are known from all over Europe, from the Kimmeridgian to the Lower Cretaceous (e.g. Fürsich and Oschmann, 1986a,b). The top of the upper Virgula Marls is thought to coincide with the base of the Tithonian Stage (H. Bläsi, 1980, pers. comm.; Meyer and Pittman, 1994; Mouchet, 1995).

The limit between the nerineoid-dominated limestones and the upper Virgula Marls is formed by a distinct hardground. This upper Nerineoid-Nanogyra-Succession (upper $\mathrm{NeNaS}$ ) is underlain by tidal to supratidal, occasionally dinosaur track-bearing biolaminites, which have been correlated with sequence boundary Kim 5 of the Tethyan domain (Colombié, 2002; Fig. 2).

In the northern part of the study area a similar succession, the lower Nerineoid-Nanogyra-Succession (lower NeNaS) crops out, which has been well dated by several ammonites ascribed to the boreal Aulacostephanoides mutabilis Sowerby, 1821-1823 or the Tethyan Aspidoceras acanthicum Oppel, 1863a ammonite zones, respectively (Fig. 2; Rameil, 2005; Jank et al., 2006a). Within the lower Virgula Marls, a claystone of approximately $1 \mathrm{~m}$ thickness with abundant Nanogyra sp. shells is referred to as the Marnes à virgula. It bears many well-preserved and partially articulated marine vertebrate remains as well as wood remains (Philippe et al., 2010). A dinosaur track-bearing biolaminite interval underlying the lower nerineoid limestone has been correlated with the boreal Kim 4 sequence boundary of Hardenbol et al. (1998) (Fig. 2; see Jank et al., 2006a,b; Colombié and Rameil, 2007).

Both the lower and upper $\mathrm{NeNaS}$ are laterally discontinuous (e.g., Gygi, 2000; Rameil, 2005; Jank et al., 2006c) and grade up into 


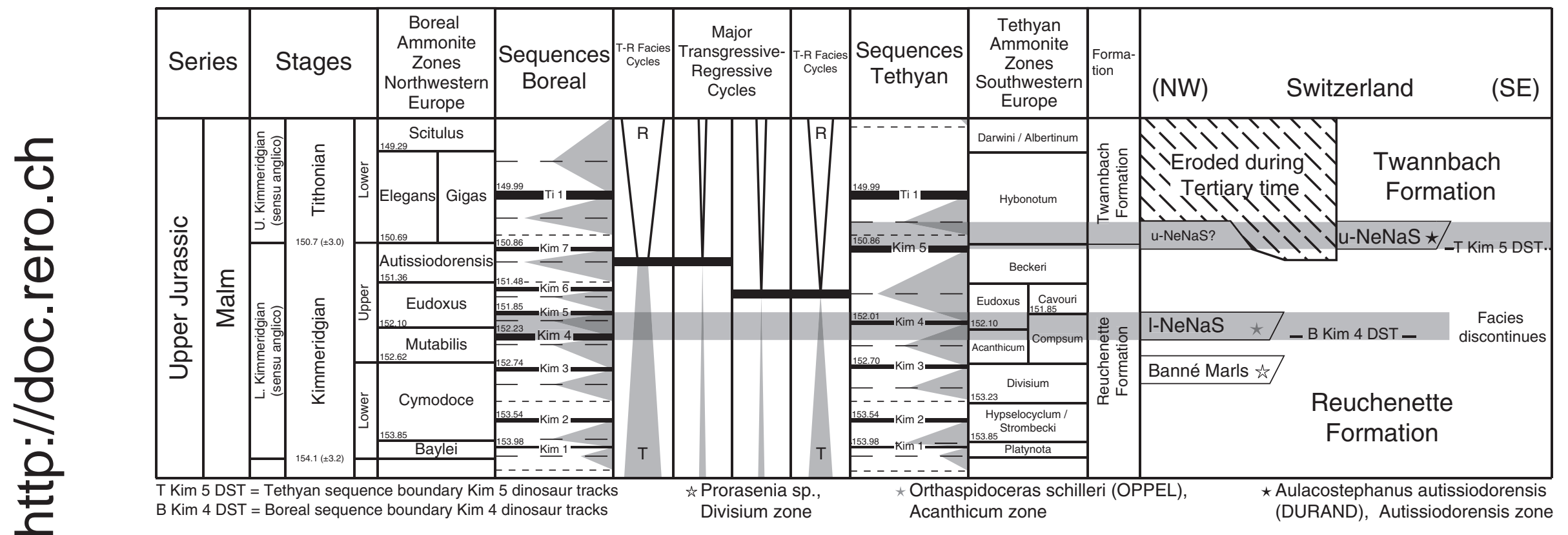

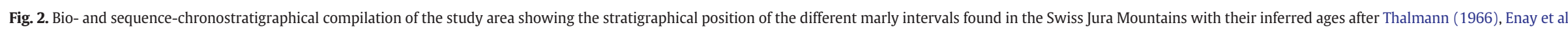

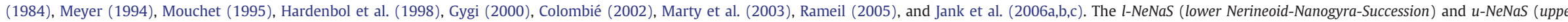
Nerineoid-Nanogyra-Succession) are dated on account of the associated ammonite fauna.

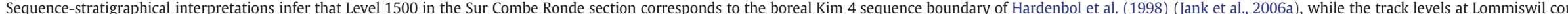
respond to the Tethyan Kim 5 sequence boundary of Hardenbol et al. (1998) (Colombié, 2002). 
a shallow-water carbonate facies. The similarity between the two successions suggests that they formed under analogous environmental conditions.

For the Late Jurassic, water depths on the platform ranged between zero and few tens of metres (Colombié and Strasser, 2005; Strasser, 2007). As the sediment thickness of generally $>120 \mathrm{~m}$ in the compacted state for the Reuchenette Formation significantly exceeds both the depositional water depth plus the space generated by sea-level rise, accommodation must have been provided by pronounced synsedimentary subsidence (Jank et al., 2006a). Late Kimmeridgian subsidence is estimated to have reached 20 to $40 \mathrm{~m} / \mathrm{Myr}$ (Wildi et al., 1989).

Carbonate production on the platform kept up with relative sealevel rise so that depositional environments remained shallow with intertidal episodes occurring repeatedly. Intermittent regressive phases led to emergence, cementation, erosion and reworking of the previously deposited sediment (Strasser and Samankassou, 2003). On this shallow, low-relief platform the low-amplitude regressive phases were sufficient to produce widespread emergence.

Sea-level changes and differential subsidence related to movements along pre-existing faults in the Hercynian basement (Allenbach, 2001; Wetzel et al., 2003) resulted in a highly structured platform with variable facies patterns (Hug, 2003; Jank et al., 2006a). Depending on subsidence, individual blocks formed swells or depressions.

\section{Material and methods}

The two stratigraphic intervals of the NeNaS were studied in 17 outcrops of which 10 were logged in detail (Table. 1, Fig. 1). In the northern part of the study area the lower NeNaS is typically developed at several sites but the uppermost part of the Reuchenette Formation including the upper NeNaS or at least the contact to the Twannbach Formation has mostly been eroded (Jank et al., 2006b). For the lower NeNaS the Courtedoux-Sur Combe Ronde section was chosen as the reference section, and was completed with data from the very nearby section Courtedoux-Tchâfouè, located less than $0.5 \mathrm{~km}$ to the $\mathrm{N}$ of Sur Combe Ronde.

In the southern part of the study area, the erosion was less pronounced and the upper NeNaS and lower Twannbach Formation are preserved (Häfeli, 1966; Fig. 2). For the upper NeNaS the Reuchenette and Frinvillier sections were chosen as reference sections. The sections Lommiswil, St. Imier and a composite section from three outcrops in the area of Neuchâtel were used for correlation and to document the lateral facies variations and the regional extent.
From the named outcrops, standard geological samples were obtained on average every $20-40 \mathrm{~cm}$, or below and above bedding planes where facies changes were observed. For all sections excepting St. Imier at least one thin-section and one polished section were prepared from each sample and analysed with respect to micro- and macrofacies and composition.

Thin-sections were studied under a standard polarised light microscope and cold cathodoluminescence microscopy was applied to selected samples. Selected thin-sections were stained for dolomite (Dickson, 1966). The mineralogical composition of selected samples was established by X-ray powder diffraction using a Philips PW 1710 diffractometer but clay mineral data was obtained from the literature. Diffractograms were recorded between $3^{\circ}$ and $65^{\circ} 2 \theta$ in step-scan mode $\left(0.02^{\circ} /\right.$ step and $\left.2 \mathrm{~s} / \mathrm{step}\right)$. The copper X-ray tube was operated at $40 \mathrm{kV}$ and $40 \mathrm{~mA}$. The CuK $\beta$ radiation was filtered with a graphite monochromator. Quantitative phase analysis by Rietveld refinement (Bish and Post, 1993) was performed by applying the SIROQUANT software package (Taylor, 1991).

A Philips FEI XL30 SFEG Sirion Scanning Electron Microscope equipped with an EDAX Energy Dispersive Spectrometer (EDS) was used to obtain backscattered electron (BSE) images, EDS point analyses and chemical maps of polished and subsequently etched slabs coated with an $\sim 4 \mathrm{~nm}$ carbon layer and covered with silver paint around the lapped surface.

\section{Section descriptions}

For the purpose of this paper, only three sections are described in detail. The other sections are documented in Waite (2010).

\subsection{Courtedoux-Sur Combe Ronde section}

In the Sur Combe Ronde section (Fig. 3), two intervals have been found, each containing several dinosaur track levels (Marty et al., 2007). The log comprises the lower NeNaS and starts with a dinosaur track interval (intermediate dinosaur track-bearing levels sensu Marty et al., 2007; level 1000, top of bed 950). The lowermost dinosaur tracks are imprinted in a bioclastic peloidal pack- to grainstone and are covered by biolaminites occasionally containing small marine bioclasts and burrows (beds 1000-1150). At least 10 bedding planes within the biolaminites exhibit dinosaur tracks and occasionally desiccation cracks. The biolaminites are capped by a $20-30 \mathrm{~cm}$ thick bed that contains oysters at the base and many marine vertebrate remains,

Table 1

List of geographical information for studied outcrops.

\begin{tabular}{|c|c|c|c|c|}
\hline Name of section & Canton & Swiss coordinates & World Geodetic System-84 & Map of Switzerland 1:25,000 \\
\hline \multicolumn{5}{|l|}{ l-NeNaS } \\
\hline Glovelier & Jura & $581.521 / 242.515$ & $07: 11: 38.91^{\circ} \mathrm{E} ; 47: 19: 59.67^{\circ} \mathrm{N}$ & No. 1085 , St. Ursanne \\
\hline Chevenez-La Combe & Jura & $567.760 / 249.660$ & $07: 00: 41.64^{\circ} \mathrm{E} ; 47: 23: 49.11^{\circ} \mathrm{N}$ & No. 1085 , St. Ursanne \\
\hline Courtedoux-Sur Combe Ronde & Jura & $568.890 / 250.040$ & $07: 01: 35.43^{\circ} \mathrm{E} ; 47: 24: 01.61^{\circ} \mathrm{N}$ & No. 1085 , St. Ursanne \\
\hline Courtedoux-Tchâfoué & Jura & $568.665 / 250.390$ & $07: 01: 24.61^{\circ} \mathrm{E} ; 47: 24: 12.09^{\circ} \mathrm{N}$ & No. 1085 , St. Ursanne \\
\hline \multicolumn{5}{|l|}{ u-NeNaS } \\
\hline Chasseral & Bern & $569.110 / 217.855$ & 07:01:53.09 ${ }^{\circ} \mathrm{E} ; 47: 06: 39.49^{\circ} \mathrm{N}$ & No. 1145 , Bieler See \\
\hline Court & Bern & $593.100 / 232.704$ & $07: 20: 50.96^{\circ} \mathrm{E} ; 47: 14: 42.79^{\circ} \mathrm{N}$ & No. 1106 , Moutier \\
\hline Enges & Neuchâtel & $566.157 / 210.859$ & $06: 59: 35.72^{\circ} \mathrm{E} ; 47: 02: 52.43^{\circ} \mathrm{N}$ & No. 1144 , Val de Ruz \\
\hline Frinvillier & Bern & $586.065 / 224.335$ & $07: 15: 17.38^{\circ} \mathrm{E} ; 47: 10: 11.39^{\circ} \mathrm{N}$ & No. 1126, Büren A. A. \\
\hline Grenchenberg & Solothurn & $594.770 / 228.088$ & $07: 22: 10.56^{\circ} \mathrm{E} ; 47: 12: 13.38^{\circ} \mathrm{N}$ & No. 1126, Büren A. A. \\
\hline Lommiswil & Solothurn & $602.800 / 231.650$ & $07: 28: 32.18^{\circ} \mathrm{E} ; 47: 14: 08.77^{\circ} \mathrm{N}$ & No. 1107, Balsthal \\
\hline Noirvaux & Neuchâtel & $529.450 / 190.025$ & $06: 30: 48.46^{\circ} \mathrm{E} ; 46: 51: 27.39^{\circ} \mathrm{N}$ & No. 1182 , St. Croix \\
\hline Pichoux & Bern & $584.138 / 236.519$ & $07: 13: 44.33^{\circ} \mathrm{E} ; 47: 16: 45.76^{\circ} \mathrm{N}$ & No. 1105, Bellelay \\
\hline Reuchenette & Bern & $585.520 / 226.400$ & $07: 14: 51.26^{\circ} \mathrm{E} ; 47: 11: 18.22^{\circ} \mathrm{N}$ & No. 1126, Büren A. A. \\
\hline Saint-Imier & Bern & $566.892 / 223.420$ & 07:00:07.22 ${ }^{\circ} \mathrm{E} ; 47: 09: 39.03^{\circ} \mathrm{N}$ & No. 1124 , Les Bois \\
\hline St. Blaise & Neuchâtel & $564.695 / 208.860$ & $06: 58: 27.02^{\circ} \mathrm{E} ; 47: 01: 47.42^{\circ} \mathrm{N}$ & No. 1144 , Val de Ruz \\
\hline Twannbach & Bern & $577.858 / 216.403$ & $07: 80: 49.08^{\circ} \mathrm{E} ; 47: 05: 53.74^{\circ} \mathrm{N}$ & No. 1145 , Bieler See \\
\hline Valangin & Neuchâtel & $559.370 / 206.618$ & $06: 54: 15.56^{\circ} \mathrm{E} ; 47: 00: 33.72^{\circ} \mathrm{N}$ & No. 1144 , Val de Ruz \\
\hline
\end{tabular}




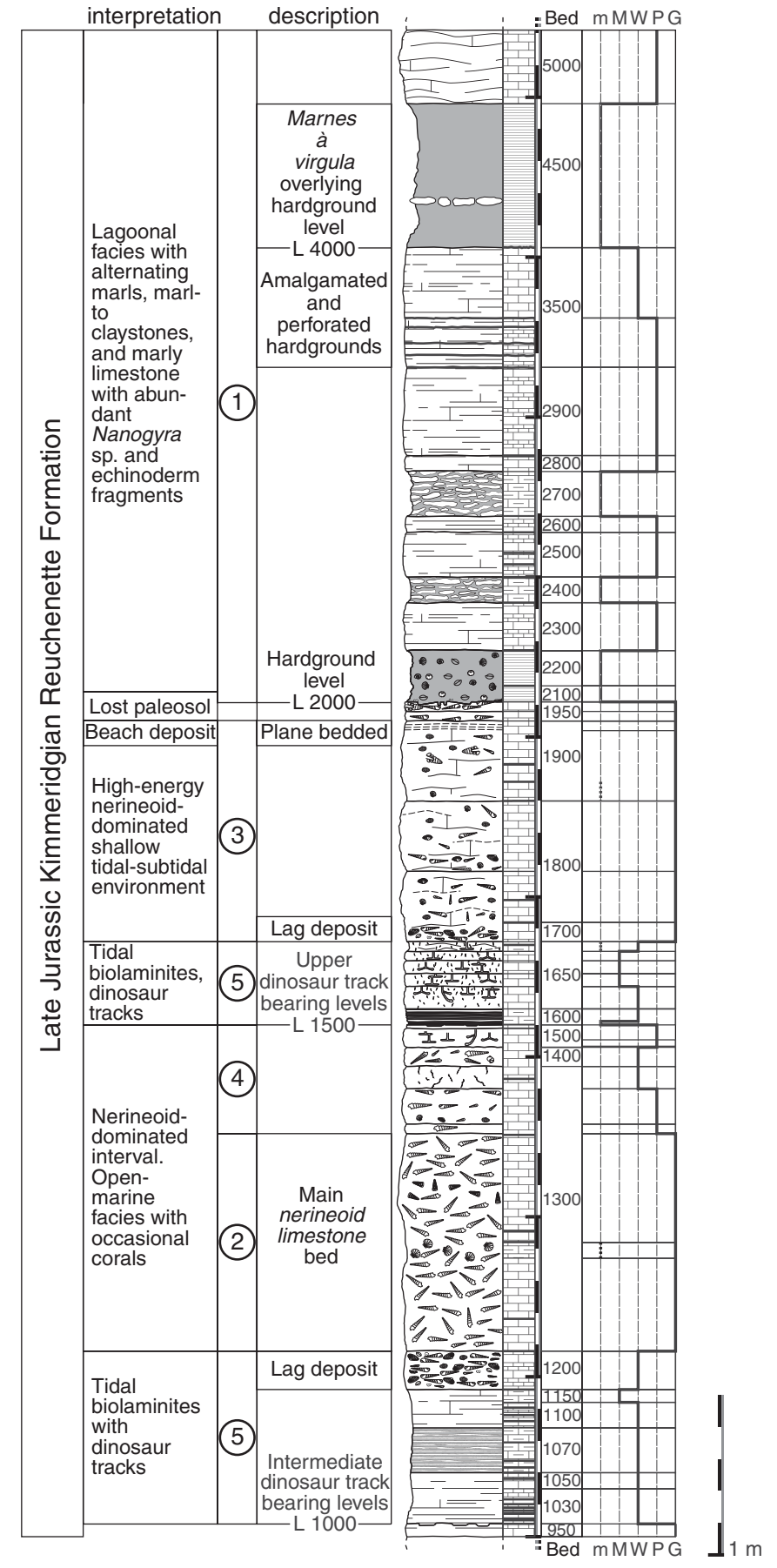

Fig. 3. Detailed log of the Courtedoux-Sur Combe Ronde section. Numbers in circles correspond to the inferred depositional environments in Fig. 10. For legend see Fig. 4.

invertebrate macrofossils and in the upper part black pebbles of several centimetres in diameter.

Above a discrete joint, the overlying main nerineoid limestones (beds 1300-1400) contain innumerable high-spired nerineoid gastropod shells (Waite et al., 2008). Up-section, an alternation between nerineoid grainstone and wackestone facies with birdseyes occurs. This is covered by a strongly bioturbated, fossil-free bed, which on the upper surface (level 1500) preserves dinosaur tracks, ripple marks, invertebrate burrows of the ichnogenus Thalassinoides Ehrenberg, 1944, marine vertebrate bones and teeth, and shows depressions and partial red staining. This surface represents the main track level of the upper dinosaur track-bearing levels (sensu Marty et al., 2007). The track-level 1500 is covered by approximately $10 \mathrm{~cm}$ of marly, track-bearing biolaminites grading into well-bedded mudstones with intercalated coarse-grained material (beds 1600-1650).

The upper track-bearing levels are followed by a 5-20 cm thick deposit (bed 1700) with oysters and locally a layer of brecciated intraclasts at the base, and with remains of marine vertebrates (turtles, crocodiles, fish) and a diverse and dense accumulation of well-preserved bivalves and gastropods. Bed 1700 is the only level below the hardground (level 2000) where kaolinite is found; it constitutes $5 \%$ of the clay mineral composition otherwise composed of illite and illite-smectite mixed-layer minerals (Marty, 2008).

This coquina is overlain by three similar beds (beds 1800-1900) with a less abundant fossil record. Nerineoids remain common and are accompanied by common bivalves, echinoderms, and occasional vertebrate remains. The uppermost $5 \mathrm{~cm}$ of bed 1900 are formed by a coarse-grained plane-bedded deposit.

This interval is capped by a $10 \mathrm{~cm}$ thick, shell-rich micro-oncoidal grainstone to nerineoid floatstone (bed 1950). The top of layer 1950 (level 2000) is a well-developed hardground covered with Trypanites Mägdefrau, 1932 and Gastrochaenolites Leymarie, 1842 borings and encrusted by "Liostrea Douvillé, 1904-type" oysters, Nanogyra nana Sowerby, 1821-1823 and serpulids; it exhibits a rough relief and erosional features.

The hardground is overlain by a greyish to greenish, chamositebearing deposit of alternating marls and marly limestones (beds 2100-2900) containing abundant Nanogyra sp. shells. The marls immediately above the hardground are composed of the clay minerals illite, I/S mixed-layers, minor amounts of smectite, and up to $20 \% \mathrm{ka}-$ olinite with small amounts of chlorite. The overlying less marly shell bed 3500 contains a rich and diverse normal-marine fauna and is locally composed of several amalgamated and perforated hardgrounds encrusted by "Liostrea-type" oysters.

Bed 3500 is topped by a well-developed hardground (level 4000) with iron crusts, local borings, and encrusting oysters, serpulids and terebratulid brachiopods (Sellithyris Middlemiss, 1959). Common ammonites (Orthaspidoceras schilleri Oppel, 1863b) and large infaunal bivalves (e.g., Ceratomya Sandberger, 1864; Pholadomya Sowerby, 1821-1823) in life position are embedded in the hardground. The bivalve steinkerns were encrusted by oysters and serpulids postmortem and presumably after the dissolution of the aragonitic shell and erosion of overlying sediment. This hardground does not show signs of emersion.

The hardground is covered by the Marnes à virgula, an up to $1 \mathrm{~m}$ thick beige to dark-grey or black marl to claystone with abundant Nanogyra virgula (Defrance, 1821). Apart from an $\sim 5 \mathrm{~cm}$ thick slightly more calcareous layer containing abundant infaunal bivalves (Myophorella Bayle, 1878) located $20-30 \mathrm{~cm}$ above the base, other invertebrates are comparatively rare. The Marnes à virgula are remarkable for the high abundance of well-preserved vertebrate remains (turtles, crocodilians, fishes) and wood preserved as lignite with branched axes reaching up to $1.75 \mathrm{~m}$ in length.

Above the Marnes à virgula carbonate content increases again and several marly, grey, micritic, fossiliferous limestone beds (layer 5000) are still dominated by densely packed shells of small oysters (probably Nanogyra sp.). Vertebrate remains are still common and the ammonite Aspidoceras caletanum Oppel, 1863a has been recovered (Jank et al., 2006a). About $5 \mathrm{~m}$ above the lower Virgula Marls, clays are almost absent and the rocks (not shown in Fig. 3) are characterised by white, chalky limestones with abundant invertebrates and corals (Coral Limestones of Jank et al., 2006b).

\subsection{Reuchenette section}

The base of the Reuchenette section (Fig. 5), is formed by a series of relatively coarse-grained occasionally bioturbated beds with frequent 


\section{Macrofauna:}

Bephalopods
Baniopods
Liostrea-type
oysters

\section{Dunham Classification:}

$\begin{array}{ll}\text { M } & \text { Mudstone } \\ \text { W } & \text { Wackestone } \\ \text { P } & \text { Packstone } \\ \text { G } & \text { Grainstone } \\ \text { m } & \text { Marl }\end{array}$

Sediment structures, lithology and components:

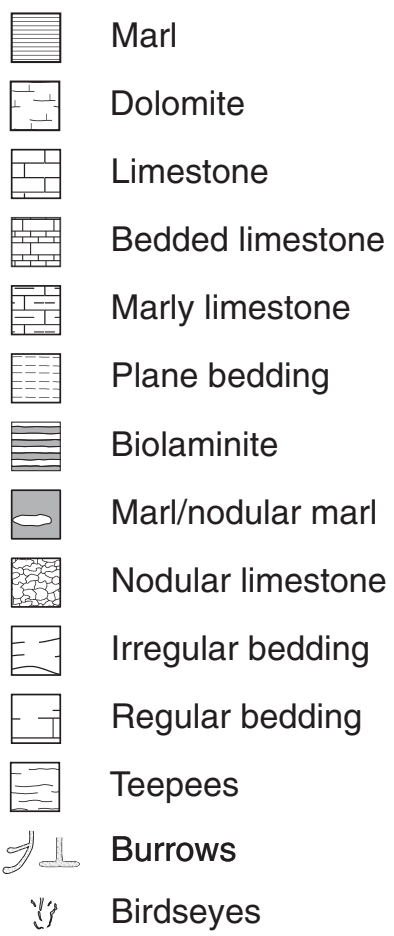

Fig. 4. Legend for Figs. 3, 5, 6 and 7 .

Classification of carbonate rocks after Dunham (1962).

dasycladacean algae and biolaminites with birdseyes (bed 92). The shallow-water interval is covered by wacke- to grainstones with frequent bivalve remains in bed 93 , which grade into a nerineoid floatstone in bed 94. Nerineoids occur throughout most of bed 96 but show the highest abundance in the middle part of the bed.

Bed 97 is a discrete bed, on average $10 \mathrm{~cm}$ thick, which contains abundant, small-centimetre-sized-turreted gastropods. Its top is developed as a conspicuous hardground. The surface is extremely flat and has a polished aspect but is heavily pocketed by Gastrochaenolites isp. borings of approximately equal depth and diameter. Encrusting organisms are absent. Shells are replaced by blocky cement, and no micritic fillings are observed. Iron-hydroxide impregnation of the rock is hardly developed and subsequent staining is weak. Iron-hydroxide occurs primarily as a millimetre-thick crust on the surface, which contains $\sim 6 \%$ goethite.

The hardground is covered by the dark echinoderm-oysterdominated marl and limestone intercalations of the upper Virgula Marls. At the base of the marls (bed 98) numerous marine vertebrate remains are recorded in addition to complete and broken Nanogyra sp. shells and other bivalves. The abundance and diversity of the faunal elements is low in the rest of the bed. The interface to the next bed is accentuated by centimetre-thick and metre-long branching Thalassinoidestype burrows. Throughout bed 99 the abundance of Nanogyra sp. shells increases to form a Nanogyra shellbed at the top, which also contains turtle remains. The overlying marl bed (100) contains abundant complete and fragmented Nanogyra sp. shells and small fish teeth. A few large marine vertebrate remains were found at the base. The two marl beds 98 and 100 are similar to the Marnes à virgula bed of the lower Virgula Marls. Bed 101 is a conspicuous coquina composed of very closelypacked, disarticulated and sometimes fragmented Nanogyra sp. shells in a marly limestone matrix. Above the marl beds, the carbonate facies is dominated by articulated, disarticulated and fragmented Nanogyra sp. and echinoderm remains. Except for the biolaminites in bed 111
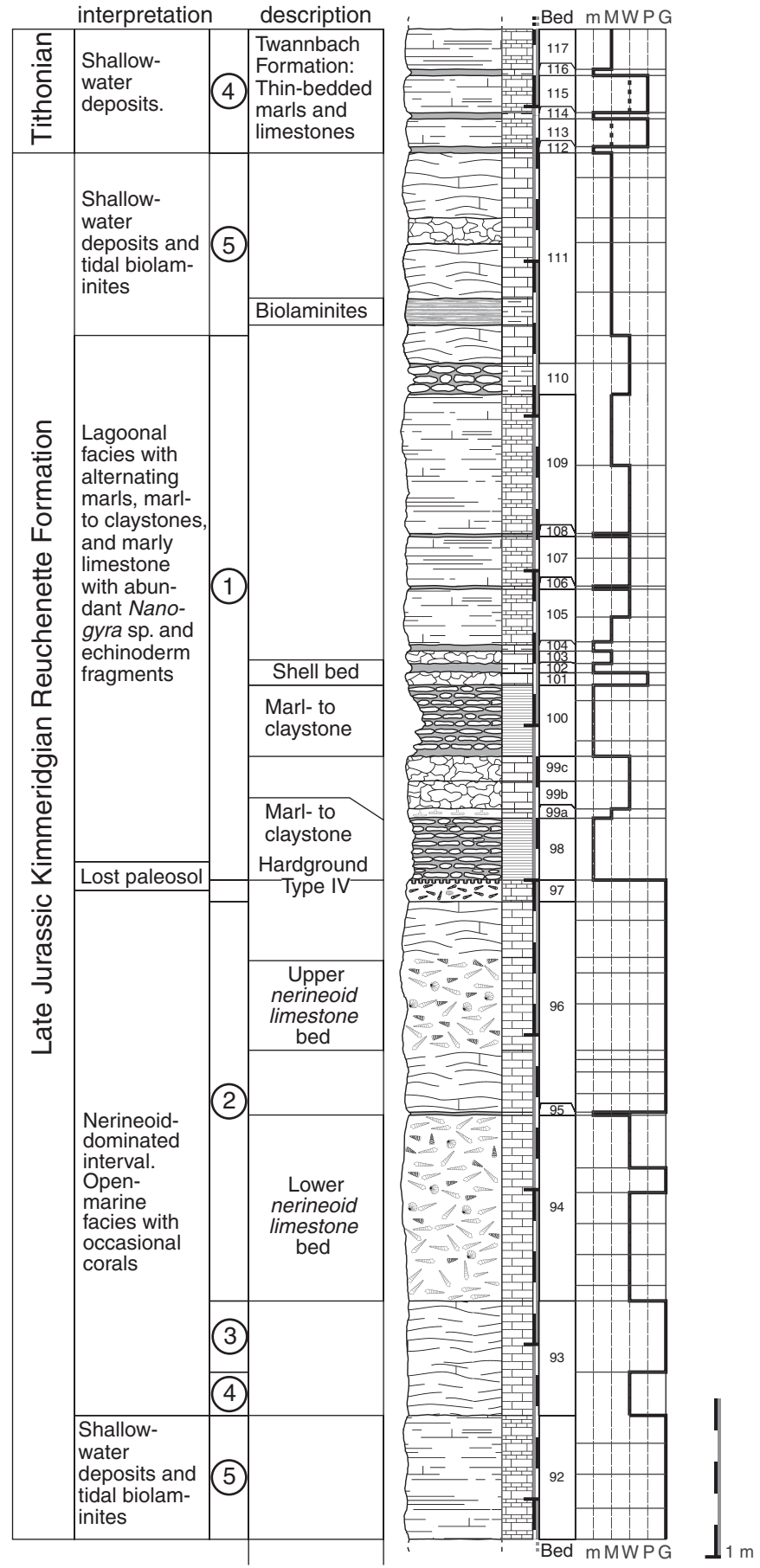

Fig. 5. Detailed log of the Reuchenette section. Numbers in circles correspond to the depositional environments in Fig. 10. For legend see Fig. 4.

echinoderm and Nanogyra sp. skeletal elements remain abundant up to the base of the Twannbach Formation in bed 117.

\subsection{Frinvillier section}

In the Frinvillier section (Fig. 6), the upper $\mathrm{NeNaS}$ is well exposed in steeply inclined strata. Because tectonic movements at this locality were concentrated along the marls, they are deformed and thinned and were, therefore, not sampled. 

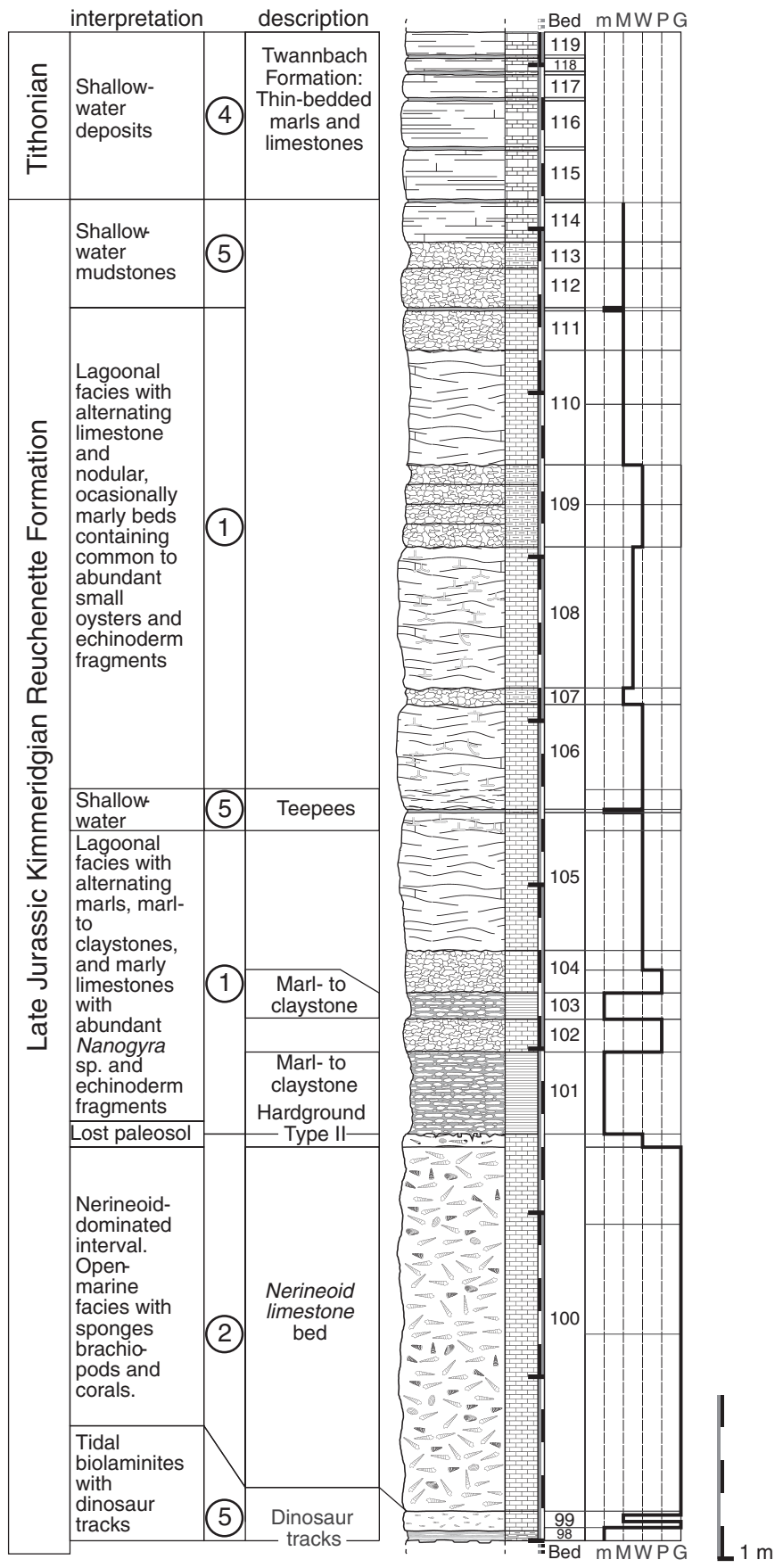

Fig. 6. Detailed log of the Frinvillier section. Numbers in circles in the second column on the left correspond to the depositional environments in Fig. 10. For legend see Fig. 4.

At the base of the logged section dinosaur tracks are found on top of a compact limestone bed and are covered by a succession of marly biolaminites (bed 98). Bed 99 is dominantly composed of small $(\sim 8 \mathrm{~mm})$ turreted gastropods and miliolid foraminifera at the base. Up-section, a level of mudstone with birdseyes occurs, which is overlain by a layer of similar gastropods as below, forming a gastropod floatstone. Above follows a massive 2.5-metre thick floatstone composed of large nerineoid shells (bed 100). At the top of bed 100, the faunal composition changes. Frequent small gastropods like in bed 99 co-occur with rare small nerineoids and frequent disarticulated bivalves of varying size.

The surface of bed 100 is a well-developed hardground with rough and sharp erosional features forming shallow crevices and grooves. It is encrusted by serpulids and Nanogyra sp. oysters and is pocked by
Gastrochaenolites isp. borings. The hardground forms the limit between the pure, light-coloured calcarenite facies and the upper Virgula Marls. It is overlain by two marl beds containing abundant Nanogyra sp. fragments separated by a nodular limestone level. The marls are covered by a succession of rather thick massive limestones intercalated with thinner nodular to slightly marly beds. Echinoderm- and Nanogyrarich wackestones dominate in the lower part and mudstones with less abundant fossil detritus are typical for the upper part. Near the top of bed 105 a level containing teepee structures occurs. The top of the section is formed by the lowest beds of the Twannbach Formation.

\section{Upper NeNaS correlation}

The correlation of the sections provides the basis for deducing the coeval lateral facies variations (Fig. 7). The closely-spaced sections Reuchenette (B) and Frinvillier (C) show all major lithofacies of the upper NeNaS and can be correlated by: (1) dinosaur track levels and/or tidal biolaminites, (2) nerineoid mass accumulations and/or hardgrounds and (3) the base of the thin-bedded limestones or marl-limestone alternations of the Twannbach Formation above the upper Virgula Marls and their inferred stratigraphic equivalents. In a north-easterly direction, the Lommiswil section (A) is correlated with the Frinvillier section by characteristic biolaminites containing the dinosaur track level immediately below the nerineoid limestones (K. Stransky, 2011, pers. comm.). The biolaminites are considered to represent a synchronous correlation horizon (line 1), which is found at the same stratigraphic position within the facies succession throughout most of the study area.

At Lommiswil, the upper Virgula Marls as such are not developed. Correlation line 2 is, therefore, not unequivocal in a north-easterly direction. A thin marl-rich limestone is most likely coeval with the hardground but the overlying marl-limestone alternation is mainly replaced by nerineoid limestones.

At St. Imier (D), biolaminites occur at the base of the section but because no larger bedding planes crop out, the presence of dinosaur tracks could not be ascertained. Above the biolaminites, a strongly bioturbated bed preserving small but clearly distinguishable Thalassinoides isp. burrows occurs, which only contains rare nerineoids. The bed is topped by a well-distinguished Nanogyra-encrusted hardground representing time line 2; it is characteristic for the central part of the study area and covers an area of at least $300 \mathrm{~km}^{2}$. The upper Virgula Marls occur as a threemetre thick interval of Nanogyra-bearing marls and marly limestones.

To the south in the Neuchâtel section (E), the upper Virgula Marls and the hardground below are not developed, and dinosaur tracks could not be found. Only the nerineoid limestones and the conspicuous change from thick beds to thin beds at the base of the Twannbach Formation occur as typical elements of the upper NeNaS. The nerineoid limestone is covered by tidal biolaminites containing truncated nerineoids. These closely resemble truncated nerineoids observed on the dinosaur track surface 1500 at Sur Combe Ronde. The correlation between the Neuchâtel section and the reference sections is primarily based on the position and facies similarities of the nerineoid limestone. The Neuchâtel section, however, appears to have been generally deposited in a shallow, possibly more restricted environment as biolaminites and birdseyes occur at several levels in the section. Furthermore, above the nerineoids, the deposits are heavily dolomitised.

\section{Depositional environments}

The deposits of the NeNaS are developed in characteristic facies, which can be attributed to specific depositional environments (Fig. 8). Facies 1 represents the lower and upper Virgula Marls including thinlayered, dark-grey marls and calcarenitic wacke- to packstones, amalgamated hardgrounds, and claystones with abundant Nanogyra sp. shells. Macrofossil remains are frequent. 

(A) Lommiswil,
(B) Frinvillier, center
(C) Reuchenette,
(D) Saint Imier,
(E) Neuchâtel, north east centre west south
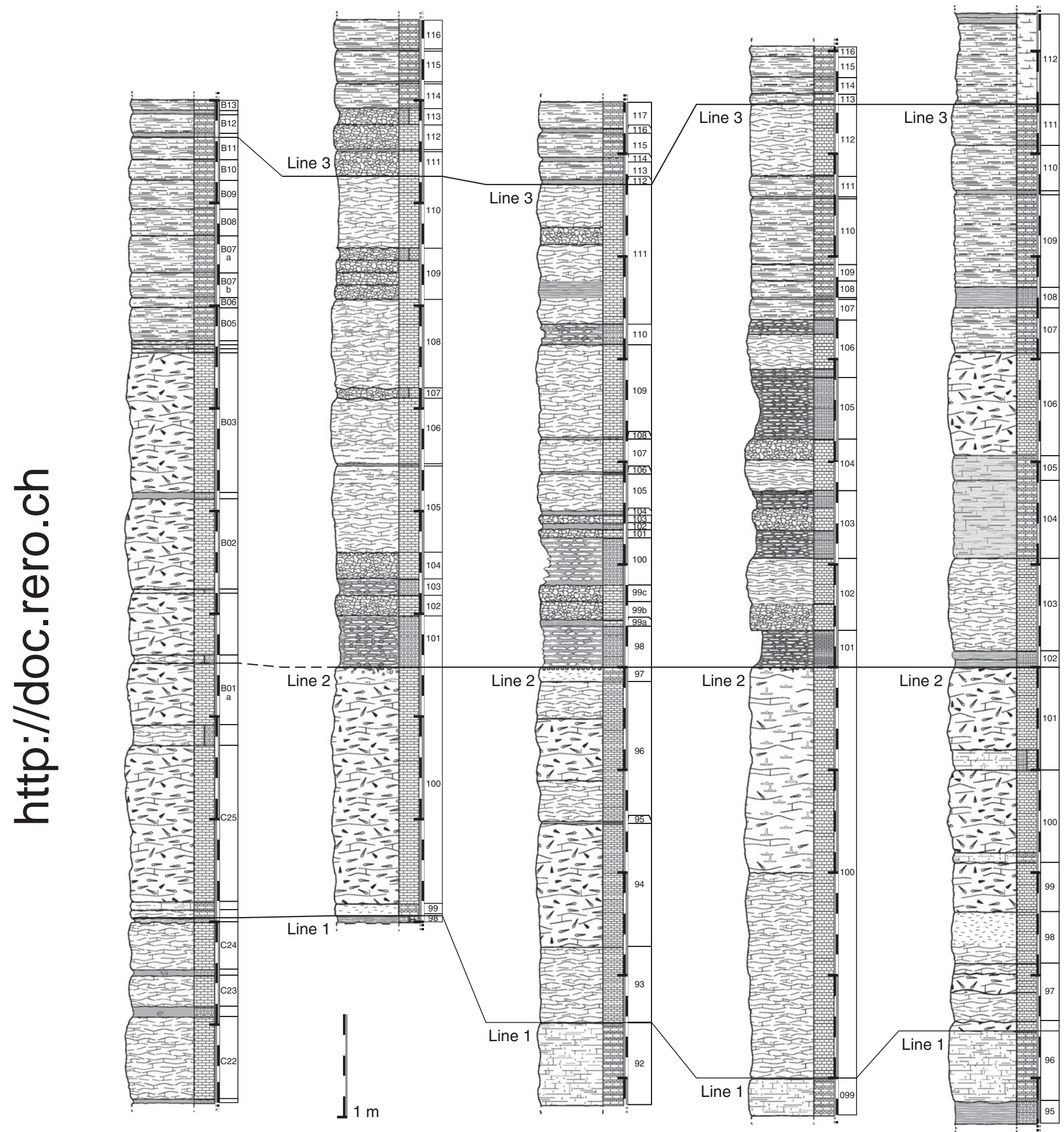

Fig. 7. Correlation of a selection of logs from the upper Nerineoid-Nanogyra-Succession. Correlation of sections is based on: Line 1 - Top of tidal biolaminites (dinosaur tracks) below the nerineoid limestone; Line 2 - Top of the nerineoid limestone (hardground in the central part of the study area; compare Fig. 2); and Line 3 - Base of the thin-bedded marls and limestones of the Twannbach Formation. For legend see Fig. 4.

This facies is interpreted to have formed in an open lagoonal environment dominated by Nanogyra sp. and echinoderms between fairweather and storm-wave-base (Jank et al., 2006a,b). During times of elevated terrestrial input, carbonate production was suffocated, leading to the formation of coquinas and submarine hardgrounds in waveand current-affected areas, and marls to claystones with abundant Nanogyra sp. and vertebrate and wood remains in calm locations. Alternatively, carbonate mud- and wackestones were deposited when 


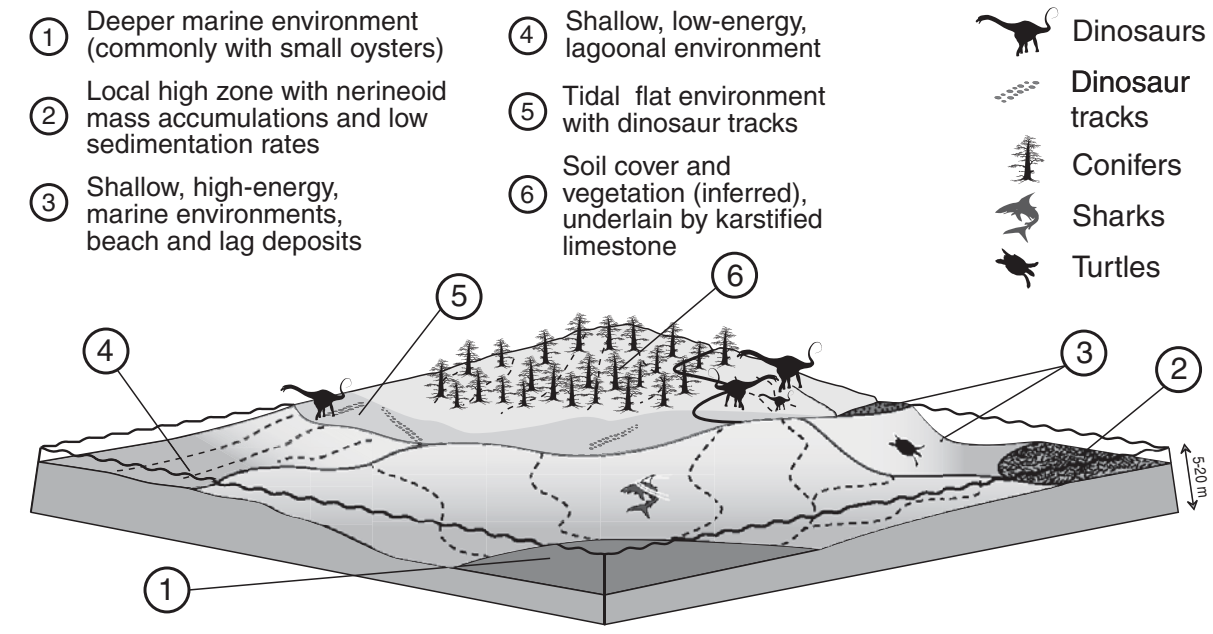

Fig. 8. Reconstruction of the depositional environments on the platform in the study area illustrating the different facies regimes. Numbers in circles correspond to the stratigraphical record found in the outcrops (Figs. 3, 5, 6).

terrigenous sediment input was low. The abundance of Nanogyraencrusted bivalves (e.g., Gervillia Defrance, 1820) and marine vertebrate remains indicate that Nanogyra sp. is preserved in situ.

Facies 2 comprises floatstones composed of innumerable nerineoid shells accompanied by sponges and occasional corals or diceratid bivalves. These mass accumulations of nerineoid gastropods are interpreted to represent semi-sessile suspension-feeding communities forming armoured carbonate accumulations on topographic swells in high-energy environments having elevated availability of labile organic carbon, stable substrate, and low sedimentation rates (Waite et al., 2008; Waite and Strasser, 2011).

Facies 3 is constituted of grainstones and packstones forming lenses and beds of packed shells and mud pebbles including black pebbles and coarse-grained plane-bedded deposits. These deposits are interpreted as high-energy, littoral environments including beach deposits, storm beds, and transgressive conglomerates (lag deposits) (e.g., Strasser, 1984; Kidwell, 1993; Meldahl, 1993).

Facies 4 consists of wacke- to packstones containing the remains of common dasycladacean algae and ostracod tests. Nerineoids are common constituents but are not dominant. Thalassinoides isp. burrows are often abundant. They are generally filled with material enriched in coarse grains. This facies is attributed to protected, low-energy, shallow lagoons where firmgrounds were colonised by burrowing crustaceans (Jank et al., 2006c). The coarse sediment within the burrows is interpreted as having been introduced during storms by wave-pumping (e.g., Tedesco and Wanless, 1991).

Facies 5 is predominantly composed of fine-grained biolaminites occasionally disrupted by birdseyes and fenestrae. On bedding planes, dinosaur tracks, desiccation cracks, and wave ripples are present. These sediments are interpreted to have formed on marginally marine, shallow-water, low-energy, tidal-flats to supratidal-flats (Marty, 2008).

Facies 6 is not found preserved, rather it is inferred on account of the plant remains in the adjacent beds and the presence of the numerous tracks of carnivorous and herbivorous dinosaurs including very small "baby" sauropods (Marty, 2008; Marty et al., 2010). This terrestrial megafauna requires extensive vegetated areas that must have been present not too far from the tracksites to provide food.

Facies 7 comprises hardgrounds that formed in high-energy coastal settings as evidenced by planar bedding, storm deposits, and wavecut terraces that strongly abraded the record of previous emergence. Therefore, hardgrounds formed during transgression not only represent non-deposition but also erosion. Because of their stratigraphic and sedimentologic significance, these hardgrounds are addressed in more detail.

\section{Hardgrounds}

The boundaries between the nerineoid-rich limestones and the marl-limestone alternations of the Virgula Marls in the lower and upper NeNaS are formed by well-developed hardgrounds of regional extent. They are conformable with respect to both underlying and overlying strata. The hiati and the pronounced environmental and bathymetric change from intertidal/supratidal to lagoonal/marine imply a considerable time gap (e.g., Read and Grover, 1977; Hillgärtner, 1998).

The features of the hardgrounds vary locally but unifying elements can be found in all outcrops. Two end-members are distinguished:

1. A relatively flat surface with shallow erosional pits and irregular, sharp crevices is locally bored and encrusted by oysters and serpulids. The rock is stained by iron-hydroxide down to a depth of $10 \mathrm{~cm}$. Such hardgrounds are found at Sur Combe Ronde (L 2000; Fig. 9) and Frinvillier (top of bed 100; Fig. 10). The surfaces are superficially karstified but larger caves or large-scale dissolution are lacking. At Sur Combe Ronde, the surface shows conical grooves preserving the external sculpture of nerineoids but the steinkerns have been washed out (Fig. 9). The surface is heavily bored showing several generations of Trypanites isp. and occasional Gastrochaenolites isp. trace fossils.

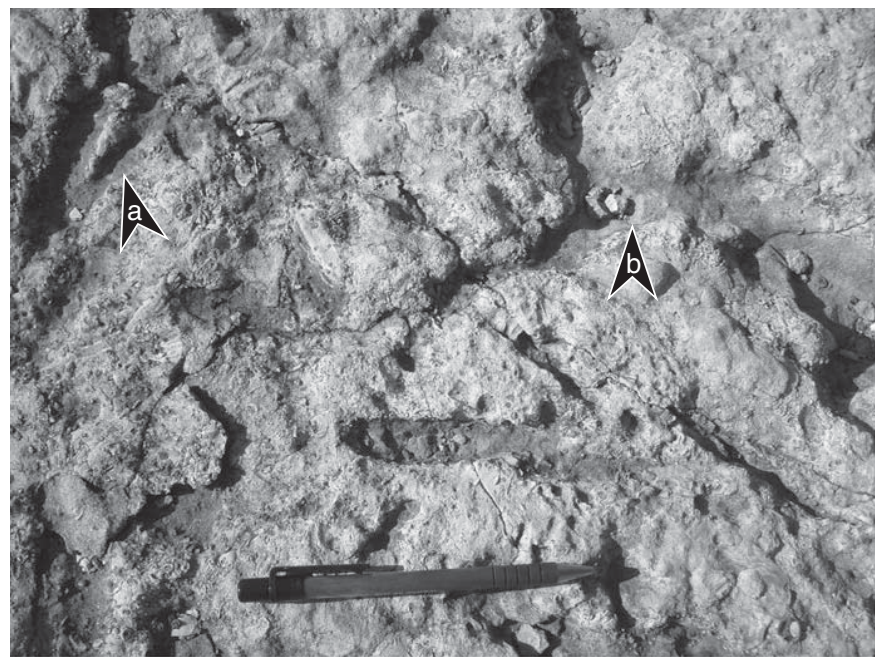

Fig. 9. Karstified and eroded hardground (level 2000) from the Courtedoux-Sur Combe Ronde section. (a) Nerineoid-shaped depression where the steinkern has been eroded out. (b) Karren, formed by run-off possibly under a soil cover. Pen for scale. 


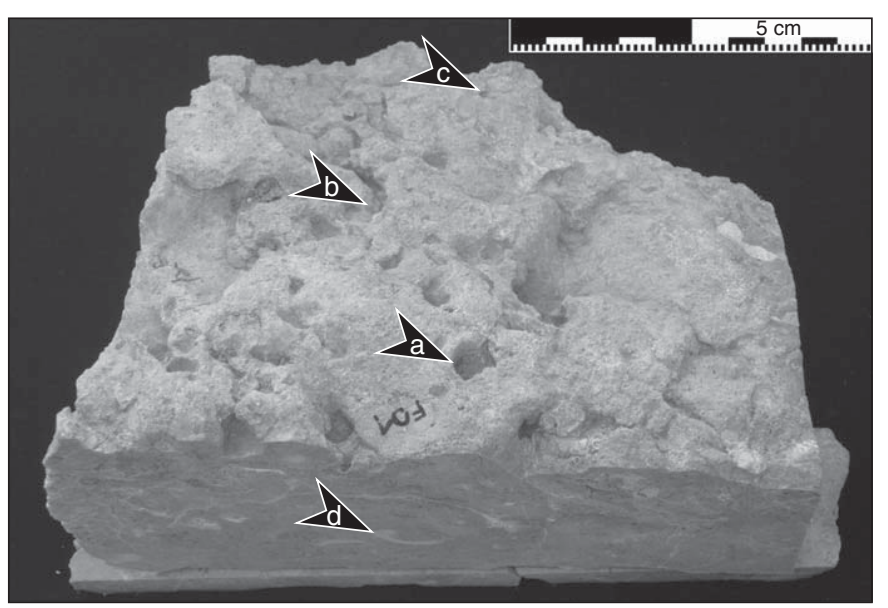

Fig. 10. Photograph of a sample from the hardground at Frinvillier, top of bed 100 . (a) Slightly eroded Gastrochaenolites isp. boring. (b) Sharp erosional karren features. (c) Nanogyra sp. encrusting the surface. (d) Disarticulated bivalve shell fragment replaced by apatite-rich micrite.

The latter have been observed still containing the trace-forming bivalves. All aragonite has been dissolved and both shell-voids and Trypanites isp. are filled with white micrite containing Nanogyra sp. fragments (Fig. 11). These fillings show a high apatite $(\sim 17 \%)$ and low goethite ( $2 \%)$ content while the bulk rock contains up to $7 \%$ of goethite.

Primary micritic meniscus cements are succeeded by micro-spar rims and overgrown by several generations of blocky calcitic cement (Fig. 12). Locally, iron-rich phases impregnated the micrite or precipitated as cryptocrystalline cement filling the intergranular pore space. At Frinvillier, some mollusc shells are replaced by micrite containing up to $7 \%$ apatite. The nuclei of ooids are commonly replaced by iron-hydroxide while the micritic calcitic rims retain their primary mineralogy. Pore space not filled by iron precipitates or micrite has been filled by blocky sparite. The iron-hydroxide impregnation penetrates down to $\sim 10 \mathrm{~cm}$, giving the rock a mottled, reddish-orange staining. The iron-hydroxide is primarily incorporated in the micritic matrix and constitutes almost $5 \%$ of the bulk rock composition. Bioturbation occurred prior to lithification, and Lithophaga Röding, 1798-type bivalves bored into the surface once the hardground had formed, producing Gastrochaenolites isp. trace fossils. The wackestone texture restricts the identification of the different cement generations. The pore-space,

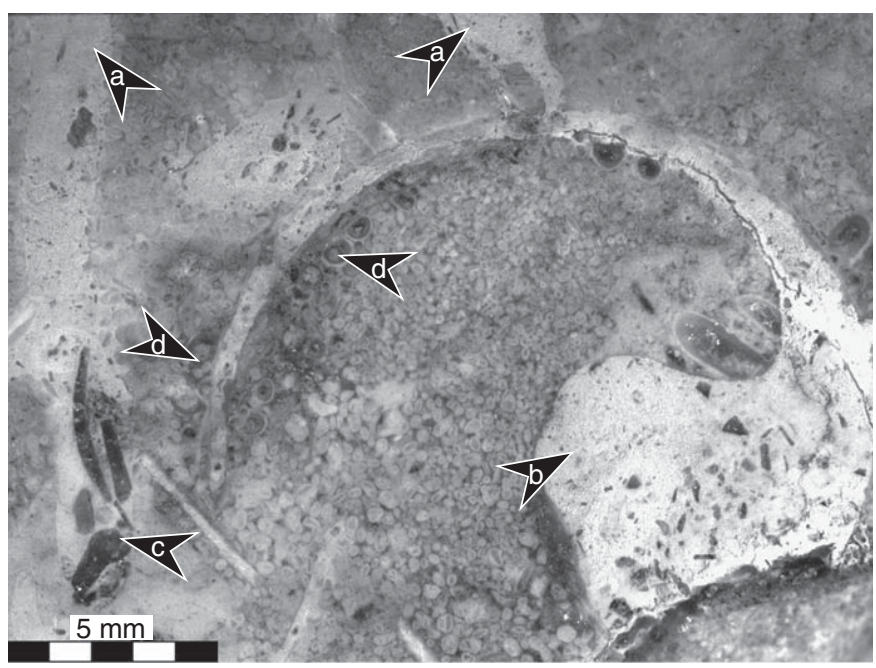

Fig. 11. Micrograph showing the micro-oncoid grainstone texture of the hardground (L 2000) at Courtedoux-Sur Combe Ronde. (a) Trypanites isp. filled with an apatiterich, marine, white, porous micrite. (b) Pseudonerinea sp. shell replaced by micrite. (c) Nanogyra sp. shell fragments in the filling of the Trypanites isp. borings. (d) Serpulids encrusting the interior and exterior walls of the shel.
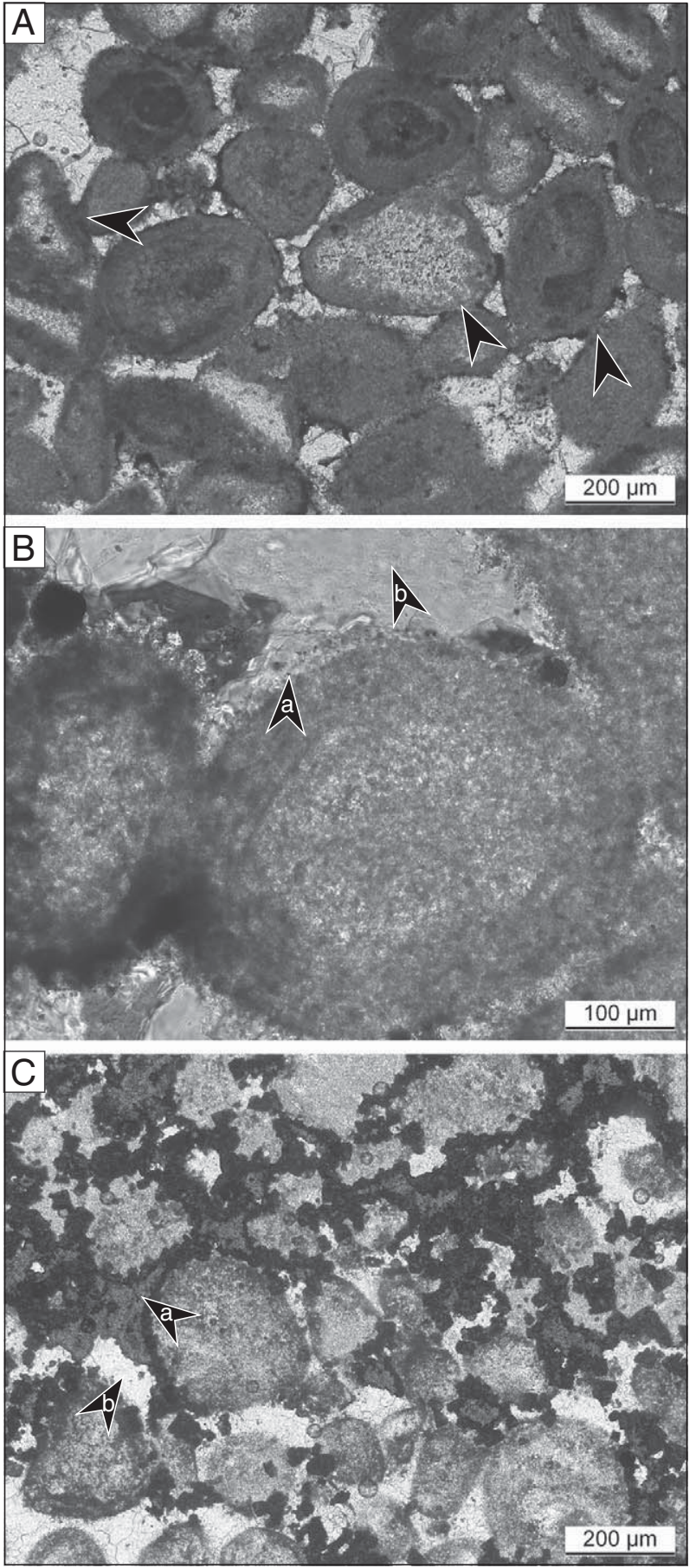

Fig. 12. Micrograph showing the different cement generations in the Courtedoux-Sur Combe Ronde hardground (L 2000). A) First cement generation consisting of micritic meniscus cements between grains (arrows). B) Second cement generation consisting of calcitic microsparite (a) forming a rim around the grains; third cement generation consisting of blocky calcitic spar (b) overgrowing the microsparite and filling the remaining pore space. C) Goethite-rich cement generation (a) encrusting the grains and filling the pore space prior to the precipitation of blocky sparite (b).

which therefore mainly corresponds to dissolved skeletal elements, is either filled with phosphorous-rich micrite or with two generations of spar. No surface sediments have infiltrated the shell voids (Fig. 10). Interpretation: These hardgrounds correspond to type-II-hardgrounds sensu Fürsich (1979), which are characterised by a relatively flat surface accentuated by shallow pits and depressions, where erosion was not strong enough to completely abrade the surface. The preservation of relatively deep and complete Gastrochaenolites isp., as well as 
encrustation, indicates that marine erosion of the rock was probably subordinate (Fig. 13). The hardground stores ample, but subtle evidence of previous emergence:

- The crevices are interpreted as micro-karst features formed beneath a soil cover (Wright, 1994; Hillgärtner, 1998).

- Some conical shaped grooves on the surface are evidently related to the erosion of nerineoid steinkerns. Karstification and dissolution of aragonitic shells are interpreted as early diagenetic features resulting from subaerial exposure.

- The iron-hydroxide mineralisation points to pedogenesis (Merino and Banerjee, 2008).

- The blocky calcitic spar indicates a phreatic freshwater zone; marine cements are not preserved.

The type-II hardgrounds satisfy most requirements in order to indicate emergence, even if pendent cements or sparitic meniscus cements indicative of the vadose zone have not been identified (Hillgärtner, 1998). Void-forming aragonite dissolution indicates the vadose zone or the calcite undersaturated phreatic zone (e.g., Moore, 2001). The substrate was already stabilised when aragonitic components were dissolved, otherwise the voids would have collapsed. Thus, an early - probably marine cementation phase was followed by meteoric, or phreatic calcite-undersaturated
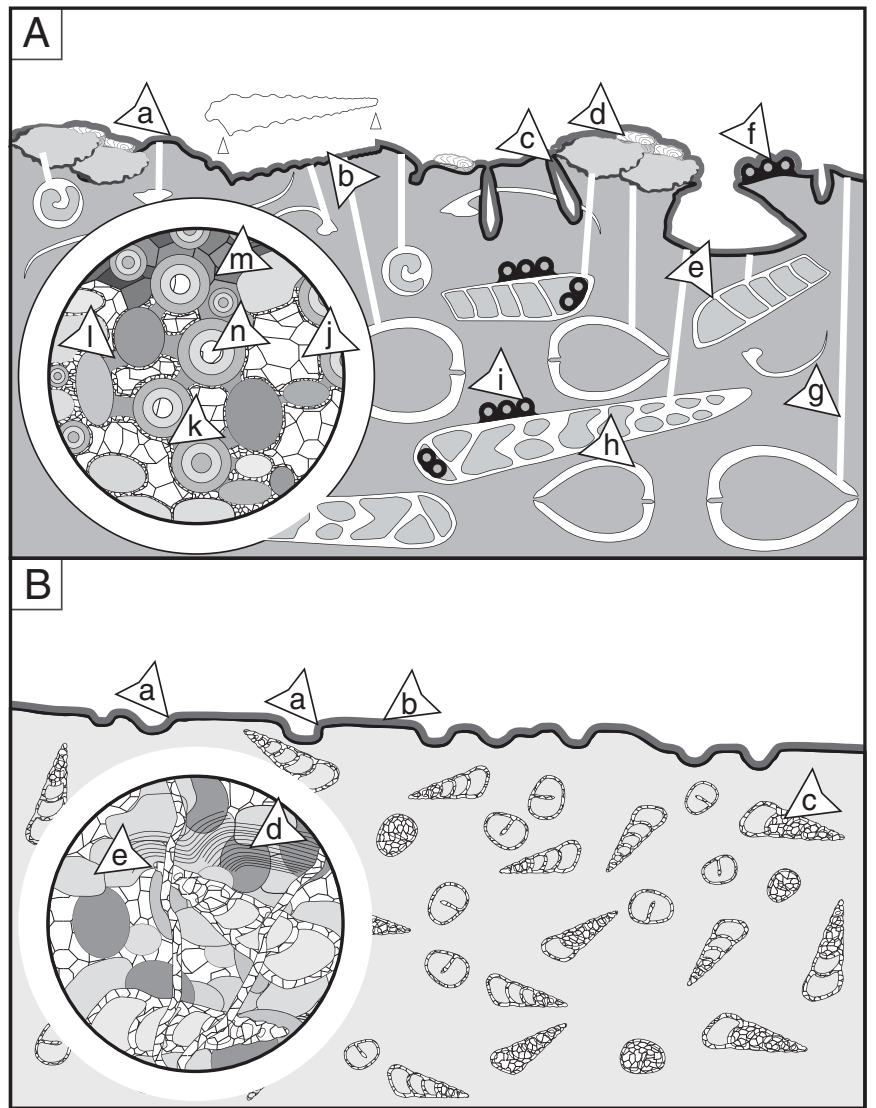

Fig. 13. Schematic depiction of hardground features. A) Type-II hardgrounds impregnated with iron-hydroxide. (a) Iron-hydroxide crust covering encrusting fauna; (b) nerineoidshaped mould where steinkern has been eroded; (c) Gastrochaenolites isp. borings; (d) encrusting Nanogyra sp. and Liostrea-type oysters; (e) karst; (f) encrusting serpulids: (g) Trypanites isp. borings filled with marine-micrite; (h) micritic shell replacement; replaced shells with (i) encrusting serpulids; (j) blocky calcitic spar; (k) calcitic microspa rims; (l) micritic meniscus cements; ( $\mathrm{m}$ ) iron hydroxide cements; ( $\mathrm{n}$ ) nuclei of ooids replaced by blocky cement. B) Type-IV hardgrounds showing only mild and mottled iron-hydroxide staining (a) Erosional truncation of Gastrochaenolites isp. borings; (b) iron crust coating the surface; (c) primary aragonite of mollusc shells replaced by blocky calcitic spar; (d) iron-hydroxide liesegang rings in micrite bending around blocky spar; e) micritised and compressed peloidal grainstone matrix. conditions. Part of the infill was probably precipitated from marine pore water as suggested by the neoformed apatite crystals documented in SEM. The Nanogyra sp. fragments indicate partial infiltration from the surface through the Trypanites isp. borings (Fig. 11). No clays were detected in the infill by XRD; therefore, the micrite was deposited prior to the overlying marls.

2. The other hardground end-member is characterised by a smooth almost polished surface, which is heavily pitted by Gastrochaenolites isp. borings. The borings are relatively wide but very shallow, indicating substantial erosional truncation of the surface. This type of hardground is especially prominent at Reuchenette (Fig. 14). The surface is not encrusted and only a thin, superficial iron-hydroxide crust is found. The hardground at Reuchenette shows two generations of blocky spar. A rim of microspar that precipitated on the grain surfaces and now forms a coating of the grains is succeeded by blocky spar that filled the remaining pore-space. No micritic cements have been observed.

Interpretation: This type of hardground matches the type-IV hardground of Fürsich (1979), being planar and heavily pitted due to bivalve borings. The dense perforation of the rock weakened the surface integrity, favouring mechanical erosion. Erosion and abrasion are thought to be related to coastal wave-cutting (Hillgärtner, 1998). No coarse-grained sediment was captured in the bioerosion pits and no conglomerates rest on the hardground in any of the studied sections. The hardground is always overlain by the marly low-energy facies. Therefore, the abrasion seems likely to be the product of wave-cutting. No marine cements are recorded, and this type of hardground lacks the early void-forming dissolution and impregnation features of the type-II hardgrounds. Furthermore, no karstification is preserved. The Reuchenette hardground records the same emersive event as the one at Frinvillier but, because of differences in exposition and erosion, unequal petrographic features resulted.

\section{Discussion}

\subsection{Dissolution and cementation}

All aragonite in the studied rocks was dissolved during diagenesis and most original aragonitic shells are preserved as moulds. Encrustation of moulds is rarely observed, indicating that the main phase of aragonite dissolution occurred after burial (Palmer et al., 1988). The high abundance of steinkerns throughout the succession suggests a relatively complete record of aragonitic faunal elements in the studied rocks (Cherns and Wright, 2009). After early lithification, meteoric diagenesis accounts for most of the loss of aragonite and the precipitation of blocky sparitic cements (e.g., Moore, 2001).

Karst features and void-rendering dissolution of aragonitic components imply subaerial exposure. Initial cementation and stabilisation of the substrate might have been relatively advanced at the time of emergence (Fürsich, 1979). Early micritic meniscus cements are formed in a number of submarine and subaerial settings where biological activity leads to an increase in alkalinity and subsequent precipitation of micrite, which may also stabilise organic filaments binding the grains. Unfortunately, micritic meniscus cements cannot be viewed as an unequivocal sign of vadose conditions (Hillgärtner et al., 2001). In the studied sections, the depth of these cements is essentially limited by the underlying bed and coincides with the depth of penetrative staining by iron-hydroxide.

The matrix of the type-II hardgrounds contains $\sim 7 \%$ goethite. The apatite-rich micrite filling of the borings and shell-voids contains only $\sim 2 \%$ goethite. As there is significantly less goethite in the fillings, it is concluded that the iron impregnation of the host rock predates the micrite infill of the voids.

Modern ferric cements, which strongly resemble those of the type-II hardgrounds, have been recorded from Safaga Bay on the Red Sea coast 


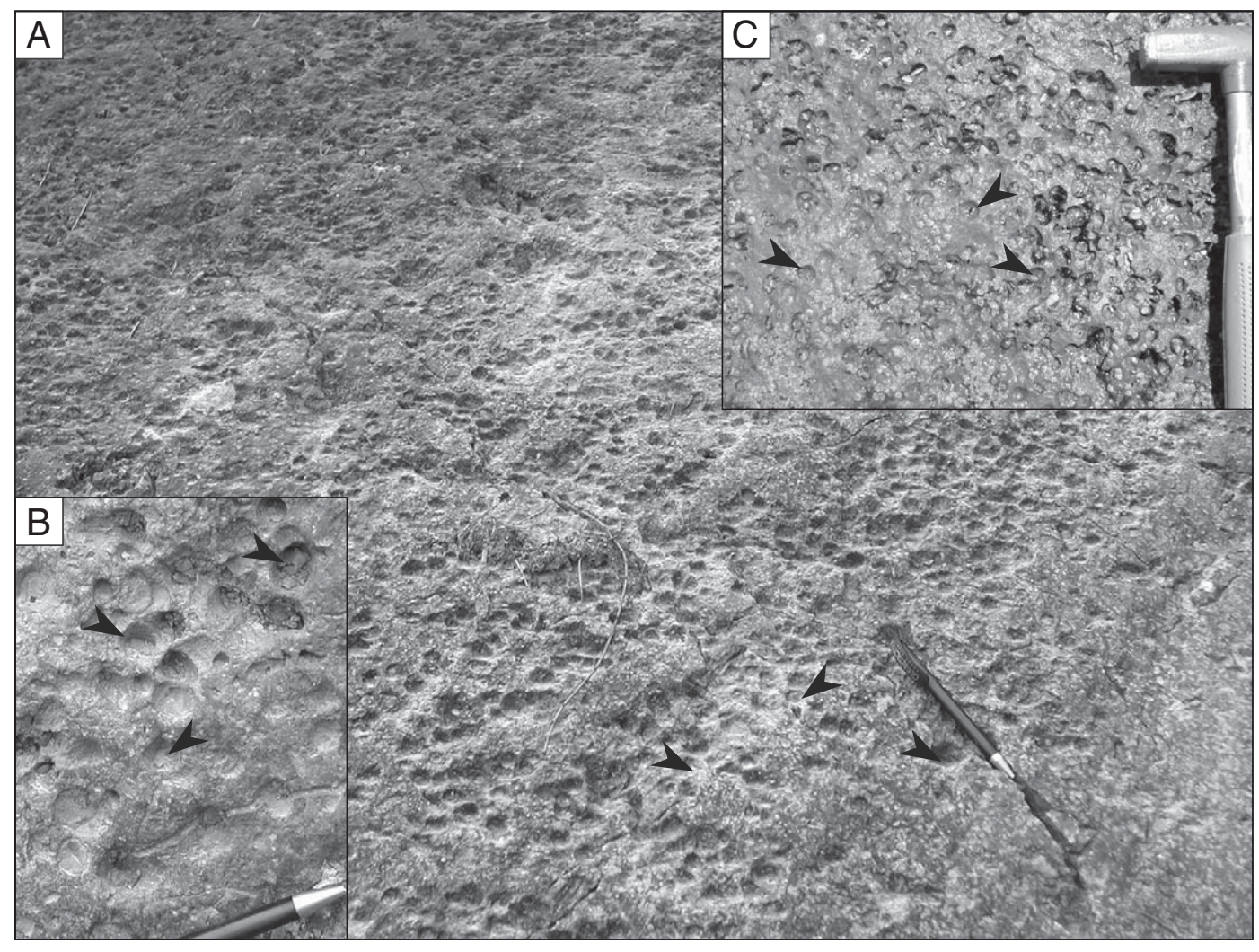

Fig. 14. Aspects of the Reuchenette hardground (B 97) surface and comparison to a Recent wave-cut terrace. A) Surface with low relief and innumerable truncated Gastrochaenolites isp. borings of similar size and depth (arrows). B) Detailed view of the borings (arrows). C) Photograph of a Recent wave-cut terrace at Ile d'Oléron on the Atlantic coast of France with similar truncated Gastrochaenolites isp. borings (arrows).

of Egypt (Fig. 15). These sub-recent cements were sampled in the vadose zone of a sabkha to tidal-flat environment at the limit between an underlying marine carbonate and overlying desert-derived siliciclastic sand. The impregnating ferric phase is amorphous and contains around $3 \%$ Fe. The mineralization appears to be located in a few-centimetrethick reaction zone at the interface between the carbonates and the siliciclastics. Abiotic and microbial processes lead to the formation of amorphous ferrihydrite $\left(\mathrm{Fe}(\mathrm{OH})_{3}\right)$, which can transform to stable minerals such as hematite $\left(\alpha-\mathrm{Fe}_{2} \mathrm{O}_{3}\right)$ and goethite $(\alpha-\mathrm{FeOOH})$ (Megonigal et al., 2004). These observations suggest that the mineralization of the studied type-II hardgrounds was related to an overlying siliciclastic source of iron.

An iron-hydroxide impregnation below and an iron-hydroxide crust above an encrusting fauna covering the studied hardgrounds require two separate phases of mineralization. First, the emerged and indurated sediment having high porosity was impregnated with iron-hydroxide while a soil formed on top. During marine flooding, the soil was eroded; the exposed carbonate surface was abraded, encrusted and bored. Subsequently, clay minerals were washed in, and deposited on the hardground and a thin crust of iron-hydroxide was precipitated at the reaction front between the carbonate and the overlying marls.

The type-IV hardground at Reuchenette shows the strongest erosion as evidenced by truncated Gastrochaenolites isp., indicating subaerial exposure but retains no primary impregnation or karstification. Only a thin crust of iron-hydroxide and a weak staining of the underlying rock is observed. Iron-hydroxide crusts are attributed to forced precipitation resulting from a steep $\mathrm{pH}$ and/or redox gradient at the boundary between carbonate and the overlying marls. Submarine precipitation of iron-oxide phases and contemporaneous dissolution of aragonite has been reported in connexion with oxidation of pyritised beds (Sanders, 2003 and example-specific references therein). However, no pyrite has been recorded from any phase in, above or below the hardgrounds and no sulphides are reported from the Virgula Marls. Furthermore, the presence of chamosite and glaucony in parts of the Virgula Marls excludes the presence of pyrite, as they cannot form together (Harder, 1980).

\subsection{Soil formation}

On an emerged carbonate platform, freshwater can account for aragonite dissolution and precipitation of early cements, thus leading to an early induration of the platform surface (Wright, 1994). Under climatic conditions with pronounced seasonal variations in precipitation and temperature, terra rossa-type soils (Alfisols (USDA)/Luvisols (FAO/ UNESCO)) can develop on limestone (Durn, 2003). On the emerged carbonate platforms far from the hinterland, siliciclastics are rare or absent, and much of the non-carbonate fraction of the soils is delivered by wind (Mirabella et al., 1992; Wright, 1994). For instance, the recent soil cover of the Bahamas contains considerable amounts of aeolian material from the Sahara (Singer, 1984; Foos, 1991; Wright, 1994). Similarly, during the Late Jurassic, the interiors of the continents experienced harsh, arid conditions (Hallam, 1993) and would have formed potential source areas for aeolian dust (Moore et al., 1992). Besides the direct accumulation of dust particles, terra rossa soils have been shown to form by replacement of carbonate by authigenic clay minerals at a metasomatic reaction front at the bedrock surface (Merino and Banerjee, 2008; Meert et al., 2009). Aeolian dust is incorporated or washed-out in rain. Rain dissolves the dust particles and carries the dominant elements $\mathrm{Fe}, \mathrm{Al}$ and $\mathrm{Si}$ in solution. Such waters become buffered in contact with limestone and lead to carbonate dissolution and karstification. Concomitantly ferrihydrite and authigenic clay minerals may precipitate at the soil-rock interface (Retallack, 1990). The ferrihydrite can impregnate the porous limestone accounting for the strong, dark red staining 


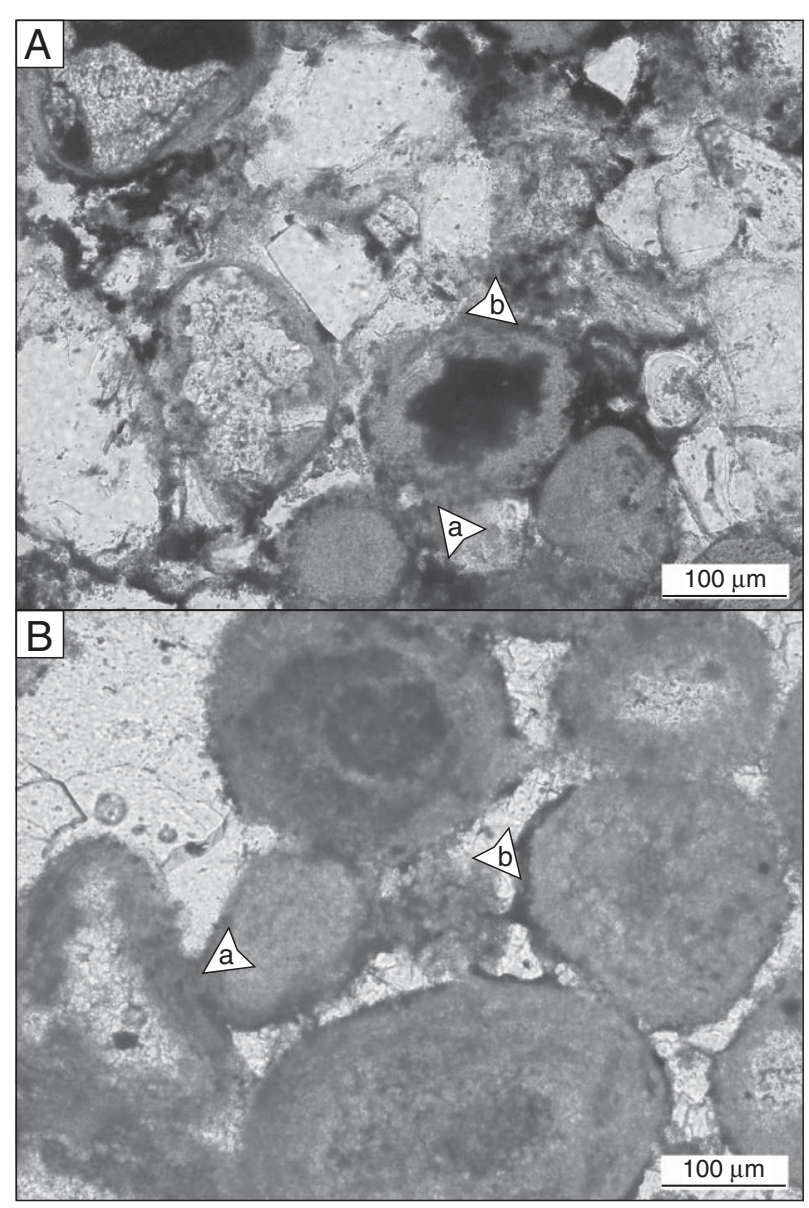

Fig. 15. Comparison of fossil and sub-recent iron-rich precipitates. A) Safaga Bay, Red Sea coast, Egypt. Micritic menisci (a) and crusts (b) developing around grains impregnated with an amorphous ferric phase. B) Hardground L 2000 at Courtedoux-Sur Combe Ronde. Micritic menisci (a) and crusts (b) developed around grains impregnated with iron-hydroxide.

(Wright, 1994; Merino and Banerjee, 2008). Ferrihydrite can recrystallise to goethite within months (Megonigal et al., 2004). Goethite is stable under oxidising humid and acidic conditions (e.g., Retallack, 1990). At temperatures higher than $40{ }^{\circ} \mathrm{C}$, it is transformed to hematite (Liu et al., 2009). In terra rossa, hematite and goethite occur together but hematite usually dominates (Durn, 2003). However, intermediate drainage in subtropical, seasonally wet, organic-rich soils can lead to weakly reducing conditions and cause selective dissolution of hematite, leaving only the goethite (Kraus and Hasiotis, 2006). Aeolian derived soils on carbonate rocks have been shown to accumulate at rates of $2.5 \mathrm{~cm} / \mathrm{kyr}$ (Meert et al., 2009). The maturity of such a soil depends on its formation time and factors such as rainfall, temperature and soil biota (Curtis, 1990).

\subsection{Vegetation}

Wood fragments occur in lagoonal deposits of the studied sections, and their good state of preservation (branches up to $1.75 \mathrm{~m}$ long) and lack of encrustation imply a rather short transport distance (Philippe et al., 2010). The plant remains recovered from the Marnes à virgula of the lower NeNaS have recently been identified as the gymnosperm conifer Protocupressinoxylon purbeckensis Francis, 1983, which grew in a seasonal climate regime. $P$. purbeckensis is described as a large tree, more than $13 \mathrm{~m}$ tall and $1.3 \mathrm{~m}$ in diameter, which grew in welldrained, thin, calcareous soils and built closed, well-developed forests
(Francis, 1984; Philippe et al., 2010). Fossil remains of such forests are well known from the Purbeckian of Dorset where the tree stumps are preserved in paleosols resting on early lithified limestone beds (Francis, 1984; Hallam, 1984).

The wood from the upper NeNaS has been recently assigned to the genus Brachyoxylon Hollick and Jeffrey, 1909 (Philippe et al., 2010). It is believed to represent a pioneering form, which is found in carbonaterich settings and can produce root-traces. Two adjacent vegetational habitats on the platform have therefore been inferred (Philippe et al., 2010).

The phosphorous in the cavity fillings of the hardground may also have been derived from a terrestrial biological source such as guano or bones. Lagoonal red terrigenous mud on the Bermudas has a phosphorous content as high as $14 \%$ (Blackburn and Taylor, 1969). The source of both clays and phosphorous in the Bermudas was deduced to be related to soil erosion, and the phosphorous was shown to be derived from guano. In analogy, it is proposed that the phosphorous, the plants, and the clays in the studied outcrops were also derived from an adjacent land area.

\subsection{Clay minerals}

Clay minerals can provide further information about the past environmental situation, as they are not diagenetically altered: the studied succession was never buried deeper than about 1000-1500 m (Loup, 1992) and the sediments have not been significantly modified by thermal diagenesis (Brigaud et al., 2009).

The marls immediately above the hardground at Sur Combe Ronde and at Tchâfouè are composed of the clay minerals illite, I/S mixedlayers, minor amounts of smectite, and up to $20 \%$ kaolinite with small amounts of chlorite. Below the hardground, clay mineral composition is dominated by illite and I/S mixed-layers (Marty, 2008). The dominance of clay minerals such as illite and chlorite indicate relatively fast erosion in the source area or formation during the initial stages of weathering (Fürsich et al., 2005).

Smectite and I/S mixed-layer minerals may form under conditions where a pronounced dry season alternates with a less pronounced wet season (Singer, 1984; Thiry, 2000). Furthermore, smectite tends to transform into iron-rich illite via an intermediate stage of mixed-layer minerals at surface temperatures under conditions of repeated wetting and drying (Deconinck and Strasser, 1987).

Kaolinite generally indicates an advanced stage of weathering; it forms under well-drained conditions in humid-subtropical to tropical climates over long periods of time (Thiry, 2000).

In the $\mathrm{NeNaS}$, the I/S-mixed-layer composition below the hardground points to a warm, seasonal, climate (e.g., Thiry, 2000). Contrarily, the clay mineral composition of the marls suggests a humid-subtropical climate with short-term climate changes of high and low rainfall where both illite and kaolinite are inherited from a highly weathered source area (Devleeschouwer et al., 2002).

Intervals with elevated proportions of kaolinite in the Reuchenette Formation have in the past been interpreted to indicate a climatic change from semi-arid, low hydrolyzing to humid-subtropical conditions (Colombié, 2002). This interpretation implies runoff from a weathered hinterland and long transport over the platform. However, kaolinite settles faster than smectite and illite on behalf of its coarser grain size (Brigaud et al., 2009; Dera et al., 2009). Thus, kaoliniterich assemblages can also simply indicate proximity to the source area. The higher proportion of kaolinite in the marls therefore could imply reworking of kaolinite-rich local soils.

Finally, when invoking aeolian dust as clay source, clay mineral composition does not carry a reliable paleoclimatic signal from the emerged platform area (Singer, 1984). Thus, clays may partially reflect the local climate in addition to inherited signals (Curtis, 1990; Merino and Banerjee, 2008). 


\subsection{Role of paleosols within the facies succession}

The platform was structurally subdivided by local swells, which formed barriers as evidenced by the coeval juxtaposition of high-energy shoals and beaches, low-energy lagoons, and tidal-flats. The pronounced differences in facies development in the study area are explained by differential subsidence (Allenbach, 2001; Wetzel et al., 2003; Allenbach and Wetzel, 2006) coupled with high-frequency eustatic sea-level changes
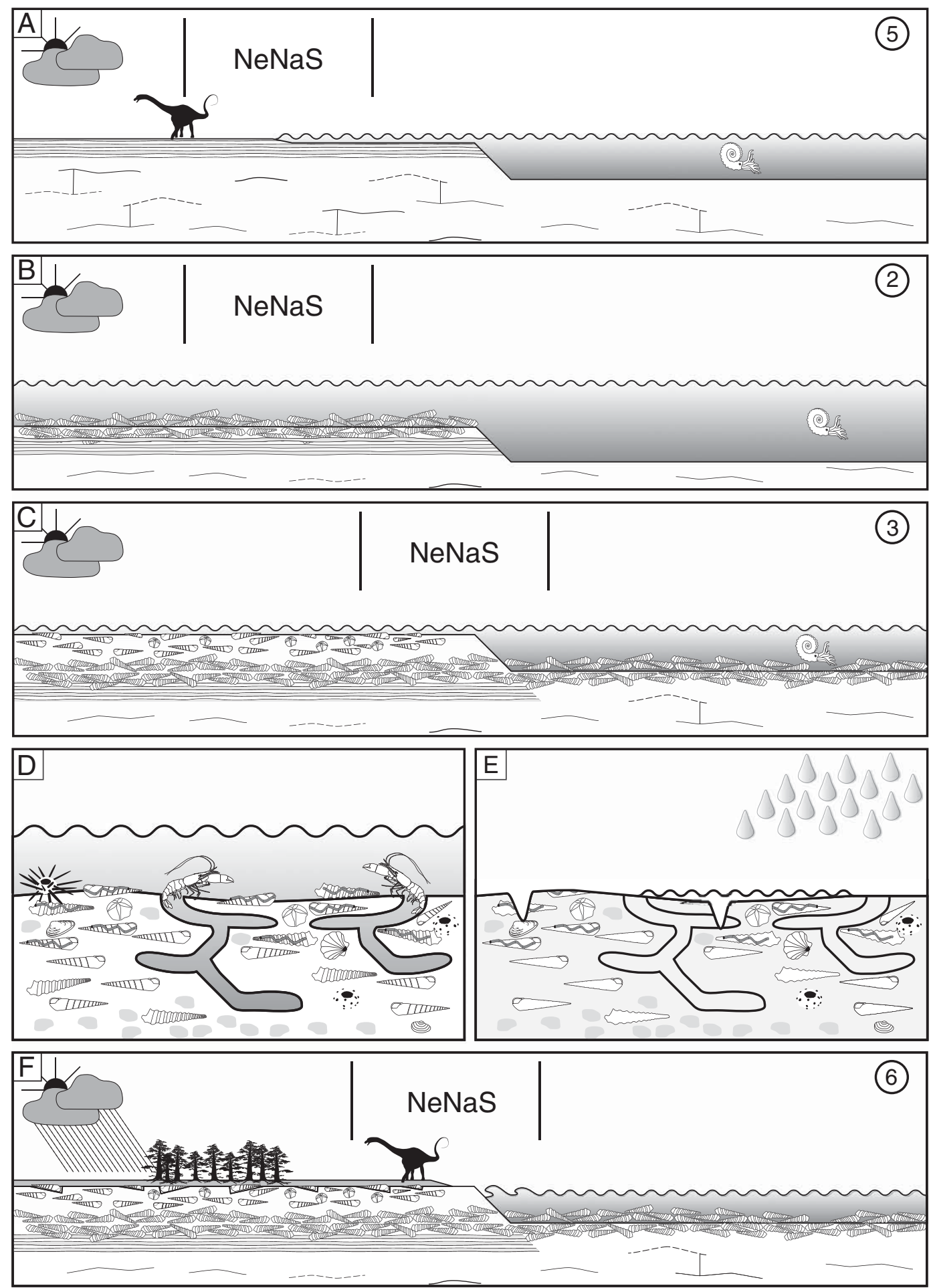

Fig. 16. Hypothetical development of the Nerineoid-Nanogyra-Successions (NeNaS) Numbers correspond to the depositional environments in Fig. 10. (A) Widespread emergence led to the formation of marginal-marine deposits with dinosaur tracks preserved in microbial biolaminites. (B) Flooding of the platform permitted the colonisation of the substrate by nerineoid gastropods indicating high-energy conditions and elevated levels of suspended food. (C) A phase of relative sea-level fall is indicated at the top of the nerineoid limestone beneath the hardgrounds but is not evident in the entire study area due to differentiated platform morphology. (D) The change in environmental conditions is evidenced by condensation and high rates of bioturbation. (E) Continued lowering of relative sea-level led to emergence of parts of the platform. Freshwater diagenesis resulted in dissolution of aragonite and cementation. Karstification of the emersive areas was initiated. (F) Soil formed on the new land, which was colonised by vegetation and formed the food basis for the colonisation of the platform by dinosaurs. 
(Colombié and Strasser, 2003; Colombié and Rameil, 2007). The resultant variations in accommodation space explain the lateral variability of the NeNaS.
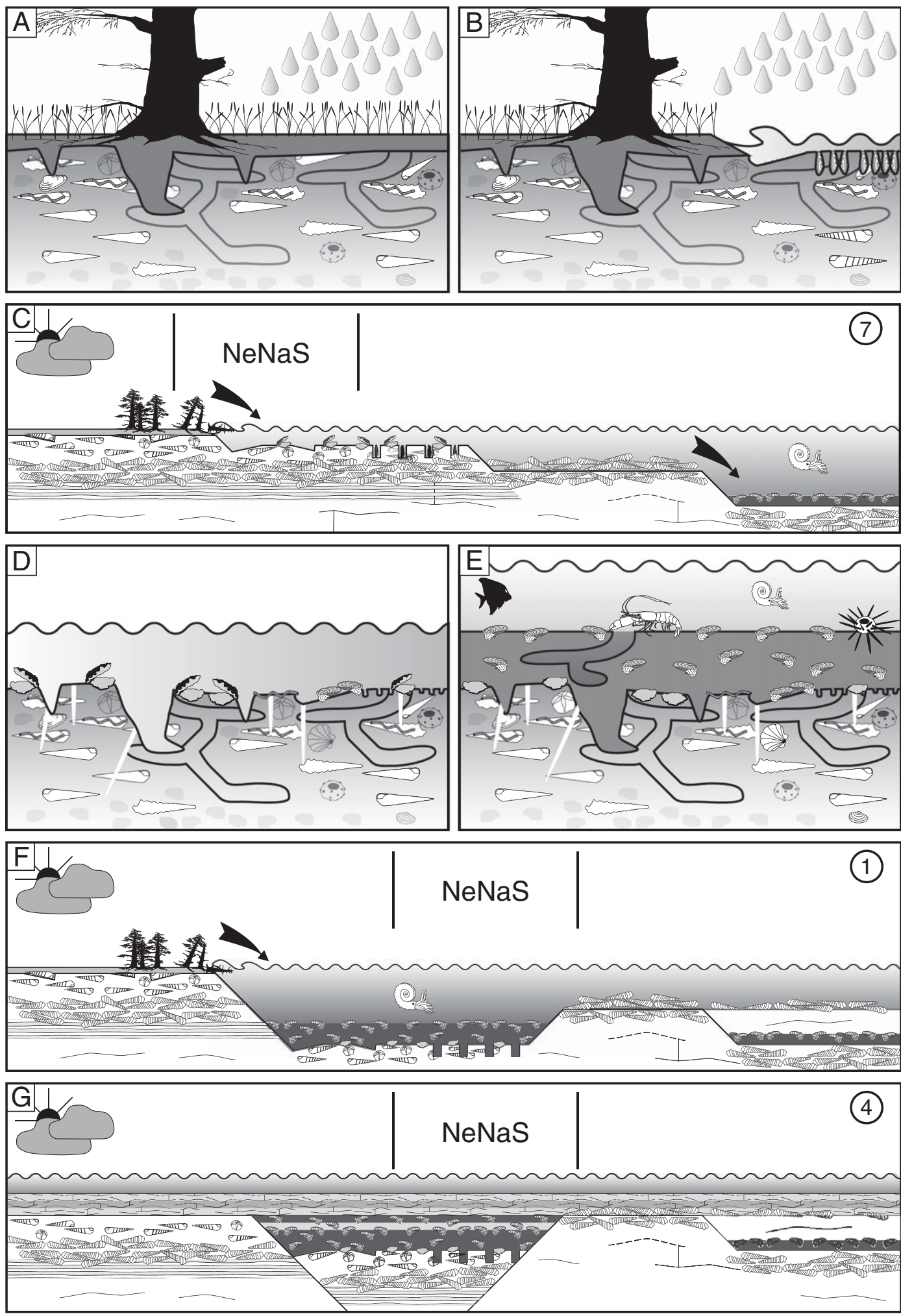

Fig. 17. (A) The authigenic formation of clay minerals at the metasomatic reaction front between the soil and underlying carbonate led to the precipitation of iron-hydroxide and subsequent impregnation of the hardground. (B) Marine flooding of the platform under high-energy conditions initiated erosion of both soils and vegetation and led to wave cutting. (C) Submerged areas were colonised by an encrusting and boring fauna and both labile and refractory organic matter were supplied into the platform waters providing the food for the nerineoids. (D) During an episode of non-deposition and rapid deepening borings and shell voids were filled with marine micrite. (E) Sedimentation was re-established and dark marls rich in plant remains and innumerable Nanogyra sp. oysters were deposited above the hardground. (F) Continuing erosion of the emerged platform supplied the suspended organic matter to sustain both Nanogyra sp. oysters and nerineoids in their respective high- and low-energy environments. (G) In the Tithonian differential subsidence discontinued, accommodation space was filled and monotonous, shallow-marine, fossil-poor, thin limestone beds were deposited over the entire study area. 
affected wide areas on the low-relief platform. A subsequent rise in sea level led to the partial inundation of the platform and the intertidal to supratidal facies was covered by - or graded into - a high-energy grainstone to nerineoid floatstone deposit. The persistent generation of accommodation during transgression permitted a prolonged phase of stable environmental conditions for the deposition of the nerineoid limestones (Fig. 16).

In the north of the study area, subsidence persisted, while a relative sea-level fall or filling-in by sediment led to a shallowing in the southern part. The marginally marine, bioturbated beds that cap the nerineoid limestones usually show signs of complex formation (lag deposit, storm accumulation) and prolonged residence time at the sediment-water interface (strong external and internal encrustation of shells). Hardground formation may have been initiated during this time. The continued drop in relative sea level led to emergence and exposure of the carbonate to meteoric water; aragonite was dissolved and early calcitic cements formed. Subsequently, microkarst- or karren-structures began to develop.

Contemporaneous formation of soil permitted vegetation to colonise the platform and provide the nutritional basis for the dinosaurs. The relatively minor karstification of the rock suggests that these conditions only prevailed for time spans of a few thousand years (Goebel et al., 1989; Bosák, 2008). The soil formation led to iron-hydroxide impregnation of the underlying limestone (Fig. 17).

The flat and discrete appearance of the surface suggests a new episode of relative sea-level rise, leading to flooding and abrasion by waves (e.g., Santos et al., 2010). This caused reworking of soil and vegetation and erosion of the underlying rock, thereby forming a wave-cut hardground. The labile organic matter and nutrients fertilised coastal waters and in turn provided the nutritional basis for the widespread mass occurrences of nerineoid gastropods and the oyster Nanogyra sp. (e.g., Hallock and Schlager, 1986; Waite et al., 2008). The hardgrounds initially experienced a period of sediment bypass, during which the rock was bored and encrusted, and apatite-rich micrite infiltrated or was precipitated from the water in the remaining pore-space (e.g., Santos et al., 2010). Differential subsidence led to relative sea-level rise over the hardgrounds while adjacent areas remained in intertidal or nerineoid facies.

Fine-grained marls accumulated once low-energy hydrodynamic conditions beneath fair-weather wave-base were reached. Depositional water depth of the marls is unlikely to have been very deep, as signs of emersion occur only a few metres below and above (Strasser, 2007). Therefore, water depth alone cannot account for the inhibition of carbonate production. The alternation of clay- and carbonate-dominated beds is interpreted as resulting from episodic soil erosion on the emerged platform. The continuing import of terrigenous mud and nutrients led to a perturbation of the carbonate production. The abundance of Nanogyra sp., the dark colour of the marls, and the common occurrence of plant remains imply high benthic food levels probably fuelled by the removal of soil and vegetation cover during transgression (Riera and Richard, 1996). In the lower NeNaS, marl sedimentation terminated gradually and oyster-rich lagoonal limestones persist above the last marl bed for some metres, before coral limestones indicate a return to shallow-marine oligotrophic conditions (Jank et al., 2006c). In the upper NeNaS, the Nanogyra-rich facies also persists for some metres before shallow-water conditions are evidenced by the occurrence of tidal biolaminites and teepee structures (Fig. 17). The change from Nanogyra-rich marls to Nanogyra-rich limestones is interpreted as the end of the terrigenous mud and nutrient supply suppressing the carbonate production. Above the upper NeNaS, differential subsidence appears to have ceased and accumulation of homogeneous, thin-bedded, fossil-poor and predominantly shallow-marine sediments began (Twannbach Formation).

\section{Conclusions}

In the shallow-marine stratigraphic context of the studied sections, lithologic and geochemical data indicate subaerial exposure of the top of the nerineoid-rich limestones prior to the submersion and deposition of Nanogyra sp.-rich marls. Several lines of circumstantial evidence, such as micro-karst features, micritic meniscus cements, void-producing aragonite dissolution, and iron impregnation support this observation. Paleosols formed on the emerged platforms, potentially fed by aeolian siliciclastic sources, concomitantly cementing the underlying lime mud, and thereby producing hardgrounds. The $\mathrm{pH}$ buffering potential of the limestone surface lead to the precipitation of less soluble phases from the pore water and the hardgrounds were impregnated with ironhydroxide during soil formation under warm, seasonal, Mediterraneanlike climatic conditions. Abundant herbivorous dinosaur tracks and fossil flora within the studied sections support local formation of soils and vegetation on the platform. However, soils were subsequently eroded and the hardgrounds heavily overprinted by wave action, encrustation, and boring during marine flooding. The juxtaposition of intertidal and lagoonal deposits necessitates tectonically driven differential subsidence. The reworked terrigenous mud and flora provided surplus nutrients, which supported mass accumulations of marine molluscs, but also led to the eutrophication and partial suffocation of the carbonate factory. The terrigenous material was finally redeposited as marl in local depressions. Although in the past, these hardgrounds have been recognised as maximum flooding surfaces, with the associated hiati, the new results suggest that these hiati may be substantially more important than previously accounted for. Not only do these hardgrounds represent the time of non-deposition associated with sea level rise, they also represent the preceding time for sea-level fall, soil formation, and subsequent soil erosion. Such long hiati - if not recognised - are problematic for sequence- and cyclostratigraphic interpretations. Taking into account the significance of the time gaps represented by these - and similar - hardgrounds will likely change future correlations in shallow marine carbonate stratigraphic analyses.

\section{Acknowledgements}

We would like to thank Susan M. Kidwell for her inspiring ideas regarding the terra rossa development and the Paléontologie A16, especially Wolfgang A. Hug, for continued support of this research. Furthermore, we wish to thank the reviewers Franz T. Fürsich and Ana Santos as well as the editor Finn Surlyk for their very detailed revisions of the manuscript and extremely constructive comments. We also acknowledge the Swiss Federal Roads Office for the funding of the excavations at Sur Combe Ronde and Tchâfouè, which provided unique fresh sections including numerous bedding planes. Further thanks go to Karl Stransky for the permission to use his samples from the Lommiswil section; Anton Probst, president of the community council of Bellach, for the permission to work in the Lommiswil quarry, as well as the community council of Péry-Reuchenette and Ciments Vigier for the permission to work in the old Reuchenette quarry. The project was financed by the Swiss National Science Foundation (Project 20-109214.05).

\section{References}

Abbink, O., Targarona, J., Brinkhuis, H., Visscher, H., 2001. Late Jurassic to earliest Cretaceous palaeoclimatic evolution of the southern North Sea. Global and Planetary Change 30, 231-256.

Allenbach, R.P., 2001. Synsedimentary tectonics in an epicontinental sea: a new interpretation of the Oxfordian basins of northern Switzerland. Eclogae Geologicae Helvetiae 94, 265-287.

Allenbach, R.P., Wetzel, A., 2006. Spatial patterns of Mesozoic facies relationships and the age of the Rhenish Lineament: a compilation. International Journal of Earth Sciences $95,803-813$.

Bayle, E., 1878. Fossiles principaux des terrains de la France. Explication de la carte géologique de France, 4 (1). Atlas. Imprimèrie Nationale, Paris 1-158.

Beurlen, K., 1958. Die Exogyren. Ein Beitrag zur phyletischen Morphogenese der Austern. Neues Jahrbuch für Geologie und Paläontologie. Monatshefte 5 (B), 197-217.

Bish, D.L., Post, J.E., 1993. Quantitative mineralogical analysis using the Rietveld fullpattern fitting method. American Mineralogist 78, 932-940.

Blackburn, G., Taylor, R.M., 1969. Limestones and red soils of Bermuda. Geological Society of America Bulletin 80, 1595-1597.

Bosák, P., 2008. Karst processes and time. Geologos 14, 19-36. 
Brigaud, B., Durlet, C., Deconinck, J.-F., Vincent, B., Pucéat, E., Thierry, J., Trouiller, A., 2009. Facies and climate/environmental changes recorded on a carbonate ramp: a sedimentological and geochemical approach on Middle Jurassic carbonates (Paris Basin, France). Sedimentary Geology 222, 181-206.

Charollais, J., Wernli, R., Meyer, C.A., Clavel, B., 2008. Découverte d'empreintes de dinosaures dans le Berriasien du Jura méridional (Ain, France). Archives Des Sciences 60, 33-40.

Cherns, L., Wright, V.P., 2009. Quantifying the impacts of early diagenetic aragonite dissolution on the fossil record. Palaios 24, 756-771.

Colombié, C., 2002. Sédimentologie, stratigraphie séquentielle et cyclostratigraphie du Kimméridgien du Jura suisse et du Bassin vocontien (France): relations plateforme - bassin et facteurs déterminants. PhD Thesis, GeoFocus. 4. Department of Geosciences, University of Fribourg, Fribourg. pp. 1-198.

Colombié, C., Rameil, N., 2007. Tethyan-to-boreal correlation in the Kimmeridgian using high-resolution sequence stratigraphy (Vocontian Basin, Swiss Jura, Boulonnais, Dorset). International Journal of Earth Sciences 96, 567-591.

Colombié, C., Strasser, A., 2003. Depositional sequences in the Kimmeridgian of the Vocontian Basin (France) controlled by carbonate export from shallow-water platforms. Geobios 36, 675-683.

Colombié, C., Strasser, A., 2005. Facies, cycles, and controls on the evolution of a keep-up carbonate platform (Kimmeridgian, Swiss Jura). Sedimentology $52,1207-1227$

Curtis, C.D., 1990. Aspects of climatic influence on the clay mineralogy and geochemistry of soils, paleosols and clastic sedimentary-rocks. Journal of the Geological Society 147, 351-357.

Deconinck, J.-F., Strasser, A., 1987. Sedimentology, clay mineralogy and depositional environment of Purbeckian green marls (Swiss and French Jura). Eclogae Geologicae Helvetiae 80, 753-772.

Defrance, A., 1820. Gervillie. In: Cuvier, F. (Ed.), Dictionnaire des Sciences naturelles, 22. Levrault, F.G., Le Normant, Paris, pp. 502-503.

Defrance, A., 1821. Huîtres. In: Cuvier, F. (Ed.), Dictionnaire des Sciences naturelles, 22. Levrault, F.G., Le Normant, Paris, pp. 20-33.

Dera, G., Pellenard, P., Neige, P., Deconinck, J.F., Puceat, E., Dommergues, J.L., 2009. Distribution of clay minerals in Early Jurassic Peritethyan seas: palaeoclimatic significance inferred from multiproxy comparisons. Palaeogeography, Palaeoclimatology, Palaeoecology 271, 39-51

Devleeschouwer, X., Herbosch, A., Préat, A., 2002. Microfacies, sequence stratigraphy and clay mineralogy of a condensed deep-water section around the Frasnian/Famennian boundary (Steinbruch Schmidt, Germany). Palaeogeography, Palaeoclimatology, Palaeoecology 181, 171-193.

Dickson, J.A.D., 1966. Carbonate identification and genesis as revealed by staining. Journal of Sedimentary Petrology 36, 491-505.

Douvillé, J.H.F., 1904. Paléontologie, mollusques fossils. In: Morgan, J.D. (Ed.), Mission Scientifique en Perse 3. Études géologiques. Partie 4. Ernest Leroux, Paris, pp. 191-380

Dunham, R.J., 1962. Classification of carbonate rocks according to depositional texture. In: Ham, W.E. (Ed.), Classification of Carbonate Rocks-A Symposium: AAPG Memoir, 1, pp. 108-121.

Durn, G., 2003. Terra rossa in the Mediterranean region: parent materials, composition and origin. Geological Croatica 56, 83-100.

Ehrenberg, K., 1944. Ergänzende Bemerkungen zu den seinerzeit aus dem Miozän von Burgschleintz beschriebenen Gangkeren und Bauten dekapoder Krebse. Palaeontologische Zeitschrift 23, 354-359.

Enay, R., Arnaud, M., Atrops, F., Barfety, J.-C., Beaudoin, B., Bernier, P., Bodeur, Y., Boullier, A., Clavel, B., Contini, D., Dardeau, G., Debrand-Passard, S., Donze, P., Elmi, S., Gaillard, C., Jaffrezo, M., Jautee, E., Lathuiliere, B., Marchand, D., Monleau, C., Menot, J.-C., Noël, D., Pascal, A., Peybernes, B., Remane, J., Tintant, H., Thierry, J., 1984. Jurassique supérieur: Malm. In: Debrand-Passard, S., Courbouleix, S., Lienhardt, M.-J. (Eds.), Synthèse Géologique du Sud-Est de la France: Mémoires Bureau de Recherches Géologique et Minières France, 125, pp. 223-286.

Foos, A.M., 1991. Aluminous lateritic soils, Eleuthera, Bahamas - a modern analog to carbonate paleosols. Journal of Sedimentary Petrology 61, 340-348.

Frakes, L.A., Francis, J.E., Syktus, J.I., 1992. Climate Modes of the Phanerozoic; The History of the Earth's Climate Over the Past 600 Million Years. Cambridge University Press, Cambridge 1-288.

Francis, J.E., 1983. The dominant conifer of the Jurassic Purbeck Formation, England. Palaeontology 26, 277-294.

Francis, J.E., 1984. The seasonal environment of the Purbeck (Upper Jurassic) fossil forests. Palaeogeography, Palaeoclimatology, Palaeoecology 48, 285-307.

Fürsich, F.T., 1979. Genesis, environments, and ecology of Jurassic hardgrounds. Neues Jahrbuch für Geologie und Paläontologie Abhandlungen 158, 1-63.

Fürsich, F.T., Oschmann, W., 1986. Storm shell beds of Nanogyra virgula in the Upper Jurassic of France. Neues Jahrbuch für Geologie und Paläontologie Abhandlungen 172, 141-161.

Fursich, F.T., Oschmann, W., 1986. Autecology of the Upper Jurassic oyster Nanogyra virgula (DEFRANCE). Paläontologische Zeitschrifft 60, 65-74.

Fürsich, F.T., Singh, I.B., Joachimski, M., Krumm, S., Schlirf, M., Schlirf, S., 2005 Palaeoclimate reconstructions of the Middle Jurassic of Kachchh (western India); an integrated approach based on palaeoecological, oxygen isotopic, and clay mineralogical data. Palaeogeography, Palaeoclimatology, Palaeoecology 217, 289-309.

Goebel, K.A., Bettis, E.A., Heckel, P.H., 1989. Upper Pennsylvanian paleosol in Stranger Shale and underlying Iatan Limestone, southwestern Iowa. Journal of Sedimentary Petrology 59, 224-232.

Gygi, R.A., 2000. Integrated Stratigraphy of the Oxfordian and Kimmeridgian (Late Jurassic) in Northern Switzerland and Adjacent Southern Germany. Birkhäuser Verlag Basel $1-151$.
Gygi, R.A., 2003. Perisphinctacean ammonites of the Late Jurassic in northern Switzerland - a versatile tool to investigate the sedimentary geology of an epicontinental sea. Schweizerische Paläontologische Abhandlungen 123, 1-232.

Häfeli, C., 1966. Die Jura/Kreide-Grenzschichten im Bielerseegebiet (Kt. Bern). Eclogae Geologicae Helvetiae 59, 565-695.

Hallam, A., 1984. Continental humid and arid zones during the Jurassic and Cretaceous. Palaeogeography, Palaeoclimatology, Palaeoecology 47, 195-223.

Hallam, A., 1985. A review of Mesozoic climates. Journal of the Geological Society of London $142,433-445$

Hallam, A., 1993. Jurassic climates as inferred from the sedimentary and fossil record. Philosophical Transactions of the Royal Society of London. Series B, Biological Sciences $341,287-296$.

Hallam, A., 2001. A review of the broad pattern of Jurassic sea-level changes and their possible causes in the light of current knowledge. Palaeogeography, Palaeoclimatology, Palaeoecology 167, 23-37.

Hallock, P., Schlager, W., 1986. Nutrient excess and the demise of coral reefs and carbonate platforms. Palaios 1, 389-398.

Hardenbol, J., Thierry, J., Farley, M.B., Jacquin, T., de Graciansky, P.C., Vail, P.R., 1998. Jurassic chronostratigraphy. In: de Graciansky, P.C., Hardenbol, J., Jacquin, T., Vail, P.R. (Eds.), Mesozoic and Cenozoic Sequence Stratigraphy of European Basins (SEPM Special Publication 60 (chart)).

Harder, H., 1980. Syntheses of glauconite at surface temperatures. Clays and Clay Minerals $28,217-222$

Hillgärtner, H., 1998. Discontinuity surfaces on a shallow-marine carbonate platform (Berriasian, Valanginian, France and Switzerland). Journal of Sedimentary Research $68,1093-1108$.

Hillgärtner, H., Strasser, A., 2003. Quantification of high-frequency sea-level fluctuations in shallow-water carbonates; an example from the Berriasian-Valanginian (French Jura). Palaeogeography, Palaeoclimatology, Palaeoecology 200, 43-63.

Hillgärtner, H., Dupraz, C., Hug, W., 2001. Microbially induced cementation of carbonate sands: are micritic meniscus cements good indicators of vadose diagenesis? Sedimentology 48, 117-131.

Hollick, A., Jeffrey, E.C., 1909. Studies of Cretaceous coniferous remains from Kreischerville, N.Y. Memoirs of The New York Botanical Garden 3, 1-76.

Hug, W.A., 2003. Sequenzielle Faziesentwicklung der Karbonatplattform des Schweizer Jura im Späten Oxford und frühesten Kimmeridge. PhD Thesis, GeoFocus, 7. Department of Geosciences, University of Fribourg, Fribourg. pp. 1-156.

Jank, M., Meyer, C.A., Wetzel, A., 2006a. Late Oxfordian to Late Kimmeridgian carbonate deposits of NW Switzerland (Swiss Jura): stratigraphical and palaeogeographical implications in the transition area between the Paris Basin and the Tethys. Sedimentary Geology 186, 237-263.

Jank, M., Wetzel, A., Meyer, C.A., 2006b. A calibrated composite section for the Late Jurassic Reuchenette Formation in northwestern Switzerland (?Oxfordian, Kimmeridgian sensu gallico, Ajoie-Region). Eclogae Geologicae Helvetiae 99, 175-191.

Jank, M., Wetzel, A., Meyer, C.A., 2006c. Late Jurassic sea-level fluctuations in NW Switzerland (Late Oxfordian to Late Kimmeridgian): closing the gap between the Boreal and Tethyan realm in western Europe. Facies 52, 487-519.

Kidwell, S.M., 1993. Taphonomic expression of sedimentary hiatuses: field observations on bioclastic concentrations and sequence anatomy in low, moderate and high subsidence settings. Geologische Rundschau 82, 189-202.

Kraus, M.J., Hasiotis, S.T., 2006. Significance of different modes of preservation to interpreting paleoenvironmental and paleohydrological settings: examples from Paleogene paleosols, Bighorn Basin, Wyoming USA. Journal of Sedimentary Research 76, 633-646.

Leymarie, M.A., 1842. Suite du mémoire sur le terrain Crétacé du Département de l' Aube. Mémoires de la Société Géologique de France 5, 1-34.

Liu, H., Guo, H., Li, P., Wei, Y., 2009. Transformation from $\delta$-FeOOH to hematite in the presence of trace Fe(II). Journal of Physics and Chemistry of Solids 70, 186-191.

Loup, B., 1992. Mesozoic subsidence and stretching models of the lithosphere in Switzerland (Jura, Swiss Plateau and Helvetic realm). Eclogae Geologicae Helvetiae $85,541-572$.

Mägdefrau, K., 1932. Über einige Bohrgänge aus dem unteren Muschelkalk von Jena. Paläontologische Zeitschrift 14, 150-160.

Marty, D., 2008. Sedimentology, taphonomy, and ichnology of Late Jurassic dinosaur tracks from the Jura carbonate platform (Chevenez-Combe Ronde tracksite, NW Switzerland): insights into the tidal-flat palaeoenvironment and dinosaur diversity, locomotion, and palaeoecology. PhD Thesis, GeoFocus. 21. Department of Geosciences, University of Fribourg, Fribourg. pp. 1-278.

Marty, D., Hug, W.A., Iberg, A., Cavin, L., Meyer, C.A., Lockley, M.G., 2003. Preliminary report on the Courtedoux Dinosaur Tracksite from the Kimmeridgian of northern Switzerland. Ichnos 10, 209-219.

Marty, D., Ayer, J., Becker, D., Berger, J.-P., Billon-Bruyat, J.-P., Braillard, L., Hug, W.A., Meyer, C.A., 2007. Late Jurassic dinosaur tracksites of the Transjurane highway (Canton Jura, NW Switzerland): overview and measures for their protection and valorisation. Bulletin für Angewandte Geologie 12, 75-89.

Marty, D. Belvedere, M. Meyer, CA., Mietto, P, Paratte, G. Lovis, C. Thüring B, 2010. Comparative analysis of Late Jurassic sauropod trackways from the Jura Mountains (NW Switzerland) and the central High Atlas Mountains (Morocco): implications for sauropod ichnotaxonomy. Historical Biology 22, 109-133.

Mazin, J.M., Hantzpergue, P., 2010. Les traces de dinosaures des sites jurassiques français (Coisia, Loulle, Plagne). In: Billon-Bruyat, J.-P.c (Ed.), La frontière franco-suisse: un petit pas pour les dinosaures. Colloque scientifique, Porrentruy 29.-30.10.2010, abstract book. Paléojura, Porrentruy, pp. 15-16.

Meert, J.G., Pruett, F.D., Merino, E., 2009. An "inverse conglomerate" paleomagnetic test and timing of in situ terra rossa formation at Bloomington, Indiana. Journal of Geology 117, 126-138. 
Megonigal, J.P., Hines, M.E., Visscher, P.T., 2004. Anaerobic metabolism: linkages to trace gases and aerobic processes. In: Schlesinger, W.H. (Ed.), Biogeochemistry. Elsevier-Pergamon, Oxford, pp. 317-424.

Meldahl, K.H., 1993. Geographic gradients in the formation of shell concentrations; PlioPleistocene marine deposits, Gulf of California. Palaeogeography, Palaeoclimatology, Palaeoecology 101, 1-25.

Merino, E., Banerjee, A., 2008. Terra rossa genesis, implications for karst, and eolian dust: a geodynamic thread. Journal of Geology 116, 62-75.

Meyer, C.A., 1990. Sauropod tracks from the Upper Jurassic Reuchenette Formation (Kimmeridgian Lommiswil, Kt Solothurn) of northern Switzerland. Eclogae Geologicae Helvetiae 83, 389-397.

Meyer, C.A., 1994. Depositional environment and paleoecology of the Solothurn Turtle limestone (Kimmeridgian, Northern Switzerland). Geobios Mémoire spécial 16, 227-236.

Meyer, C.A., Pittman, J.G., 1994. A comparison between the Brontopodus ichnofacies of Portugal, Switzerland and Texas. In: Lockley, M.G., Dos Santos, V.F., Meyer, C.A., Hunt, A.P. (Eds.), Aspects of Sauropod Paleobiology. GAIA, Lisboa, pp. 5-14.

Meyer, C.A., Thüring, B., 2003. Dinosaurs of Switzerland. Comptes Rendus Palevol 2, 103-117.

Meyer, C.A., Thüring, B., Wetzel, A., 2006. The hitch-hikers guide to the Late Jurassic basement structures provide clues to dinosaur migration routes. Hantkeniana 5, 96

Middlemiss, F.A., 1959. English Aptian Terebratulidae. Paleontology 2, 94-142.

Mirabella, A., Costantini, E.A.C., Carnicelli, S., 1992. Genesis of a polycyclic Terra Rossa (chromic cambisol on rhodic nitisol) at the Poggio del Comune in Central Italy. Zeitschrift für Pflanzenernährung und Bodenkunde 155, 407-413.

Moore, C.H., 2001. Carbonate reservoirs: porosity evolution and diagenesis in a sequence stratigraphic framework. Developments in Sedimentology, 55. Elsevier, Amsterdam $1-460$.

Moore, G.T., Hayashida, D.N., Ross, C.A., Jacobson, S.R., 1992. Paleoclimate of the Kimmeridgian Tithonian (Late Jurassic) world 1. Results using a general-circulation model. Palaeogeography, Palaeoclimatology, Palaeoecology 93, 113-150.

Mouchet, P., 1995. Le Kimméridgien du Jura central. Microfaciès, minéralogie et interpétation séquentielle. PhD Thesis. Faculté de Sciences, Université de Neuchâtel, Neuchâtel. pp. 1-204.

Oppel, A., 1863a. Über jurassische Cephalopoden III. Paläontologische Mittheilungen aus dem Museum des Königlich bayerischen Staates 1, 163-266.

Oppel, A., 1863b. Über Ostindische Fossilreste aus den Secundären Ablagerungen von Spiti und Gnari-Khorsum in Tibet. Paläontologische Mitteilungen aus dem Museum des Königlich bayerischen Staates 4, 267-288.

Palmer, T.J., Hudson, J.D., Wilson, M.A., 1988. Paleoecological evidence for early aragonite dissolution in ancient calcite seas. Nature 335, 809-810.

Philippe, M., Billon-Bruyat, J.-P., Garcia-Ramos, J.C., Bocat, L., Gomez, B., Piñuela, L., 2010. New occurrences of the wood Protocupressinoxylon purbeckensis Francis: implications for terrestrial biomes in southwestern Europe at the Jurassic/Cretaceous boundary. Palaeontology 53, 201-214.

Rameil, N., 2005. Carbonate sedimentology, sequence stratigraphy and cyclostratigraphy of the Tithonian in the Swiss and French Jura Mountains. PhD Thesis, GeoFocus. 13. Geological Department, University of Fribourg, Fribourg. pp 1-246.

Read, J.F. Grover, G.A., 1977. Scalloped and planar erosion surfaces, Middle Ordovician limestones, Virginia: analogues of Holocene exposed karst or tidal rock platforms. Journal of Sedimentary Petrology 47, 956-972.

Rees, P.Mc., Noto, C.R., Parrish, J.M., Parrish, J.T., 2004. Late Jurassic climates, vegetation, and dinosaur distributions. Journal of Geology 112, 643-653.

Retallack, G.J., 1990. Soils of the Past: An Introduction to Paleopedology. Unwin Hyman, Boston 1-520.

Riera, P., Richard, P., 1996. Isotopic determination of food sources of Crassostrea gigas along a trophic gradient in the estuarine bay of Marennes-Oléron. Estuarine, Coastal and Shelf Sciences 42, 347-360.

Röding, P.F., 1798. Museum Boltenianum sive catalogus cimeliorum e tribus regnis naturæ quæ olim collegerat Joa. In: Fried Bolten, M.D. (Ed.), annos proto physicus Hamburgensis. Pars secunda continens conchylia sive testacea univalvia, bivalvia \& multivalvia. Trappii, T.J.C., Hamburgi, pp. 1-199 (p. d. per XL).

Sandberger, F., 1864. Beobachtungen im mittleren Jura des Badischen Oberlandes. Würzburger naturwissenschaftliche Zeitschrifft 5, 1-22.
Sanders, D., 2003. Syndepositional dissolution of calcium carbonate in neritic carbonate environments: geological recognition, processes, potential significance. Journal of African Earth Sciences 36, 99-134.

Santos, A., Mayoral, E., da-Silva, C.M., Cachão, M., Kullberg, J.C., 2010. Trypanites ichnofacies: Palaeoenvironmental and tectonic implications. A case study from the Miocene disconformity at Foz da Fonte (Lower Tagus Basin, Portugal). Palaeogeography, Palaeoclimatology, Palaeoecology 292, 35-43.

Singer, A., 1984. The paleoclimatic interpretation of clay-minerals in sediments - a review. Earth-Science Reviews 21, 251-293.

Sowerby, J.D.C. 1821-1823. The mineral conchology of Great Britain, 3-4. J.D.C. Sowerby, London. Sowerby, G.B.I., 1821-1834. The Genera of Recent and Fossil Shells, for the Use of Students, in Conchology and Geology. G.B.I., Sowerby, London. Stampfli, G., Borel, G., Cavazza, W., Mosar, J., Ziegler, P.A., 2001. The paleotectonic atlas of the periTethyan domain. European Geophysical Union, Karlsruhe 1 (CD).

Strasser, A., 1984. Black-pebble occurrence and genesis in Holocene carbonate sediments (Florida Keys, Bahamas, and Tunisia). Journal of Sedimentary Petrology 54, 1097-1109.

Strasser, A., 2007. Astronomical time scale for the Middle Oxfordian to Late Kimmeridgian in the Swiss and French Jura Mountains. Swiss Journal of Geosciences 100, 407-429.

Strasser, A., Samankassou, E. 2003. Carbonate sedimentation rates today and in the past: Holocene of Florida Bay, Bahamas, and Bermuda vs. Upper Jurassic and Lower Cretaceous of the Jura Mountains (Switzerland and France). Geologia Croatica 56, 1-18.

Taylor, J.C., 1991. Computer program for standardless quantitative analysis of minerals using the full powder diffraction profile. Powder Diffraction 6, 2-9.

Tedesco, L.P., Wanless, H.R., 1991. Generation of sedimentary fabrics and facies by repetitive excavation and storm infilling of burrow networks. Holocene of South Florida and Caicos Platform. B.W.I. Palaios 6, 326-343.

Thalmann, H.K., 1966. Zur Stratigraphie des oberen Malm im südlichen Berner und Solothurner Jura. Mitteilungen der naturforschenden Gesellschaft Solothurn 22, 4-125.

Thierry, J., Barrier, E., Abbate, E., Alekseev, A.S., Ait, O.R., Ait, S.H., Bouaziz, S., Canerot, J., Georgiev, G., Guiraud, R., Hirsch, F., Ivanik, M., Le, M.J., Le, N.Y.M., Medina, F., Mouty, M., Nazarevich, B., Nikishin, A.M., Page, K., Panov, D.L., Pique, A., Poisson, A. Sandulescu, M., Sapunov, I.G., Seghedi, A., Soussi, M., Tchoumatchenko, P.V., Vaslet, D., Vishnevskaya, V., Volozh, Y.A., Voznezenski, A, Walley, C.O., Wong, T.E., Ziegler, M., Ait, B.L., Bergerat, F., Bracene, R., Brunet, M.F., Cadet, J.P., Guezou, J.C., Jabaloy, A., Lepvrier, C., Rimmele, G., de, W.P., Baudin, F., Belaid, A., Bonneau, M., Coutelle, A., Fekirine, B., Guillocheau, F., Hantzpergue, M., Hippolyte, J.C., Julien, M., Kokel, F., Lamarche, J., Mami, L., Mansy, J.L., Mascle, G., Pascal, C., Robin, C., Sihamdi, N., Saintot, A., Stephenson, R., Vera, J.A., Vuks, V.J., 2000. Early Tithonian (141-139 Ma). In: Dercourt, J., Gaetani, M., Vrielynck, B., Barrier, E., Biju Duval, B., Brunet, M.F., Cadet, J.P., Crasquin, S., Sandulescu, M. (Eds.), Peri-Tethys Atlas; Palaeogeographical Maps; Explanatory Notes. Commission for the Geologic Map of the World, Paris, pp. 98-110.

Thiry, M., 2000. Palaeoclimatic interpretation of clay minerals in marine deposits: an outlook from the continental origin. Earth-Science Reviews 49, 201-221.

Waite, R. 2010. The palaeoecology of high-spired gastropods and the lost palaeosols: depositional reconstructions on a shallow carbonate platform (Late Kimmeridgian, Swiss Jura Mountains). PhD Thesis, GeoFocus. 23. Department of Geosciences, University of Fribourg, Fribourg. pp. 1-149.

Waite, R., Strasser, A., 2011. A comparison of recent and fossil large, high-spired gastropods and their environments. The Nopparat Thara tidal flat in Krabi, South Thailand versus the Swiss Kimmeridgian carbonate platform. Facies 57, 223-248.

Waite, R., Wetzel, A., Meyer, C.A., Strasser, A., 2008. The paleoecological significance of nerineoid mass accumulations from the Kimmeridgian of the Swiss Jura Mountains. Palaios 23, 548-558.

Wetzel, A., Allenbach, A., Allia, V., 2003. Reactivated basement structures affecting the sedimentary facies in a tectonically "quiescent" epicontinental basin: an example from NW Switzerland. Sedimentary Geology 157, 153-172.

Wildi, W., Funk, H., Loup, B., Amato, E., Huggenberger, P., 1989. Mesozoic subsidence history of the European marginal shelves of the alpine Tethys (Helvetic realm, Swiss plateau and Jura). Eclogae Geologicae Helvetiae 82, 817-840.

Wright, V.P. 1994. Paleosols in shallow marine carbonate sequences. Earth-Science Reviews 35, 367-395. 